\title{
Influence of Sources and Rates of Mineral Nitrogenous Fertilization and Bio-Stimulants on Garlic Productivity and Efficiency of Its Extracts against Pathogen Activities
}

\author{
Sameh A. M. Moussa', Hala A. Abd El-Aal' ${ }^{2}$, Ashraf M. M. Nofal ${ }^{2}$ \\ ${ }^{1}$ Sabaheya Horticultural Research Station, Horticulture Research Institute, A.R.C., Egypt. \\ ${ }^{2}$ Sustainable Development Department, Environmental Studies \& Research Institute, Sadat City Univ., \\ Egypt.
}

\begin{abstract}
Garlic is a worldwide important vegetable crop, and increase its growth and productivity a crucial objectives especially via good agricultural practice; i.e., mineral nitrogen fertilization and bio-stimulants. Two field experiments were conducted to study the influence of nitrogen fertilizer sources (ammonium sulphate and ammonium nitrate), rates (90 and $120 \mathrm{~kg} \mathrm{~N} / \mathrm{fed}$.) and bio-stimulants (Halex-2, yeast extract, Halex-2 + yeast extract and without bio-stimulants) as well as their interactions on vegetative growth, productivity, bulb quality and chemical constituents of garlic (Allium sativum, L.). Moreover, garlic extracts were tested against two pathogen activities (Fusarium oxysporium and Alternaria alternate). Garlic cloves were planted during two winter seasons of 2013/2014 and 2014/2015 at a newly reclaimed area at Sadat City, Egypt. Inoculation garlic plants with bio-stimulants showed superior effects on most of the studied characters especially for garlic productivity. Most of the studied vegetative characters, yield, yield components and bulb quality characteristics significantly affected with nitrogen sources, nitrogen rates and bio-stimulants as well as their interactions during the two seasons. Inoculation garlic plants with Halex-2 + yeast extract was found to have positive effective in reducing the mineral nitrogen fertilizer being applied by $25 \%$ as compared with the commonly recommended dose. Data revealed that the fertilization combination treatments; $120 \mathrm{~kg}$ nitrogen $/$ fed. at the form of ammonium sulphate + Halex-2 + Yeast extract and 90 nitrogen $\mathrm{kg} / \mathrm{fed}$. at the form of ammonium sulphate + Halex-2 + Yeast extract significantly gave the highest values for phenol content. The plant extracts obtained from the same two previous fertilization combinations gave the highest inhibition against Fusarium oxysporium and Alternaria alternate. The in vitro results showed that using concentration $2.5 \%$ of the selected extracts gave the highest mycelial growth inhibition for the tested pathogens. These results may contribute to develop environmentally safer alternatives antifungal agent against plant pathogenic fungi.
\end{abstract}

Key words: Garlic (Allium sativum, L.), nitrogenous fertilization, bio-fertilizer, Halex-2, yeast extract, bio-stimulants, phenol content, garlic extract, antifungal activities, Fusarium oxysporium and Alternaria alternate.

\section{Introduction}

Generally, garlic (Allium sativum, L.) is one of the oldest horticultural crops worldwide. Garlic is considered one of the most important vegetable crops all over the world. Garlic possess some medicinal characteristics such as power suppliers, insecticidal, anti-bacterial, antifungal, anti-cancer, depressor for both blood sugar and blood lipids, and reduce blood platelet aggregation (Agusti, 1990). Egypt is ranked fourth in the world in terms of the productivity of garlic (244.626 MT) after China, India and Korea (FAO, 2011). Abou El-Magd (2012) pointed out that the productivity of garlic in Egypt in 2008 has reached (301270 ton) according to the Egyptian Statistics of Ministry of Agriculture. Nitrogen fertilization is necessary and important for increasing the productivity and quality of vegetable crops such as garlic and thus is more gainful for farmers (Gulser, 2005). For good agricultural practices of garlic, it needs numerous factors which must be considered include planting time, time, rate of fertilizers, application and optimum plant population (Brewster and Butler, 1989). The published articles declare that adding an appropriate quantity of nitrogenous fertilization during sprouts stage, leads to promote vigorous vegetative growth and optimum leaf expansion (Stork et al., 2004). Kakara et al. (2002) reported that increasing nitrogen units from 50 to $200 \mathrm{~kg}$ per/ha exhibited a positive effect on the mean values of plant height, leaf area, leaf count, and fresh and dry plant mass. Therefore, use of nitrogenous fertilization is necessary for establishing successful vegetative growth of garlic. The obtained results of Mudziwa (2010) indicated that $A$. sativum plants that received higher amounts of ammonium sulphate fertilizer (100, 150 and $200 \mathrm{~kg} / \mathrm{ha}$ ) had, significantly, higher yield values as compared to garlic plants that received the lowest level of fertilization $(50 \mathrm{~kg} / \mathrm{ha})$. Nitrogenous fertilization sources (ammonium sulphate and calcium nitrate) affected plant growth and yield of garlic. The positive and significant response of garlic to applied nitrogen fertilizer has been reported by many researchers (Kilgori et al., 2007; Brahma and Yousuf, 2008; El-Zohri and Abdou, 2009 and Zaman et al., 2011).

Halex-2 is a bio-fertilizer which is considers as a non-symbiotic N2 fixing bacteria that has greater 
amounts of bacteria which responsible for fixing of nitrogen. Application of Halex-2 to the growing plants enhanced the following values; increasing soil fertility, reducing the usage of nitrogenous fertilization and expanding the availability of various nutrients to plant absorption (Abdel-Razzak and El-Sharkawy, 2013).

The role of yeast extract as bio-stimulant for growing plants was reported through its stimulatory effects on cell division and enlargement, as well as, the chlorophyll formation, synthesis of proteins and nucleic acids (Wanas, 2002 and 2006), in addition to its content of cryoprotective agent (sugars, protein , amino acids and several vitamins) as reported by (Mahmoud, 2001).

The pathogenic fungi of the plant cause many plant diseases that lead to large losses of crops production. Synthetic fungicides; generally, are applied by the farmers as a way to conserve and prevent plants, infection plant diseases. The indiscriminate and excessive usage of a wide range of fungicides has led to increased environmental pollution and the emergence of groups of pathogens that have acquired immunity to resist chemical pesticides. Therefore, the demand for organic agricultural products is increasing day by day. Based on these requirements, many researchers have been interested with the integrated control of fungal diseases, including the usage of antagonistic microorganisms and safer chemicals such as food preservatives and derived products from plants (Copping and Menn, 2000). Sulfur compounds, plant extracts, aromatics and volatile compounds resulting from secondary plant metabolism, widely applied in the fields of folk medicine, food flavor and preservation; in addition to their use in the perfume industry. For centuries, sulfur compounds have been known as antifungal (Lazarević et al., 2011). The extracts of garlic, either from leaves or bulbs, were used as antibacterial, fungal and viral infections; as well as, using as an immune system booster (Kaye et al., 1995). Numerous studies indicated that each of garlic and onion plants have biological and medicinal activities. These activities are mainly because they include high percentages of organo-sulphur compounds content. These natural bioactive chemicals have no toxic effects. Therefore, a number of recent researches have started to take advantage towards plant extracts to be commercially produced (Kim et. al., 2003 and Bajpai et. al., 2009). In the present study, the effects of methanolic extracts of garlic (Allium sativum) plant extracts on controlling the growth of two of the most important phytopathogenic fungi (Fusarium oxysporium and Alternaria alternate) in Egypt were studied.
Hence, the aims of the present study are to minimize the usage of nitrogen in form of mineral fertilizers; in addition to, maximize garlic productivity through the use of appropriate combination between two mineral nitrogen sources, nitrogen rates and bio-stimulants. Moreover, the study was intended to provide natural alternatives to the chemical fungicides to obtain healthier and safer plant products via diagnosis the fungicidal impact of garlic extract in order to perform natural alternative healthier, safer and cheaper bio-fungicide products.

\section{MATERIALS AND METHODS}

Two field experiments were carried out during two winter seasons of 2013/2014 and 2014/2015 at a newly reclaimed area, at the Environmental Studies and Researches Institute Farm, Sadat University, Minufiya Governorate, Egypt. Chinese garlic (Allium sativum, L.) cultivar was planted under drip irrigation system on $1^{\text {st }}$ of September 2013 and $7^{\text {th }}$ of September 2014. Cloves were planted in rows 10 $\mathrm{m}$ long, $60 \mathrm{~cm}$ wide at spacing of $10 \mathrm{~cm}$ within row and on both sides of the rows. The treatments of the given experiments were as follows:

1- Nitrogen source treatments:- two mineral nitrogen fertilizers; i.e., ammonium nitrate $\left(\mathrm{NH}_{4} \mathrm{NO}_{3}\right), 33.5 \% \mathrm{~N}$. and ammonium sulphate $\left(\mathrm{NH}_{4}\right)_{2} \mathrm{SO}_{4}, 20.6 \% \mathrm{~N}$.

2- Applied nitrogen rate treatments:- two nitrogen rates; i.e., $90 \mathrm{~kg} \mathrm{~N} /$ fed. and $120 \mathrm{~kg} \mathrm{~N} /$ fed. (recommended dose by the Egyptian Ministry of Agriculture.

3- Bio-stimulants treatments: - four treatments; i.e., Halex-2, yeast extract, Halex-2 + yeast extract in addition to without bio-stimulants treatment.

Each experimental unit (sub-sub-plot) was consisted of two rows with plot area of $12 \mathrm{~m}^{2}$. Each replicate had 32 rows represent the applied fertilization treatments.

\section{Agricultural practices}

The following fertilizers were added to the soil at preparation; $75 \mathrm{Kg} \mathrm{P}_{2} \mathrm{O}_{5} / \mathrm{fed}$. in the form of mono calcium phosphate $\left(15.5 \% \mathrm{P}_{2} \mathrm{O}_{5}\right)$, sulphur was applied at the rate of $200 \mathrm{Kg} / \mathrm{fed}$. plus 5 tons/fed of compost. Potassium fertilizer was added at the rate of $96 \mathrm{Kg} \mathrm{K} \mathrm{K}_{2} \mathrm{O} / \mathrm{fed}$. in the form of potassium sulphate $\left(48 \% \mathrm{~K}_{2} \mathrm{O}\right)$ throughout the drip irrigation system. All other agricultural practices for garlic production were followed as recommended in the area.

At the $2^{\text {ed }}$ of April, 2014 and $10^{\text {th }}$ of April, 2015 when the leaves had started withering, plants of each sub-sub-plot were harvested separately. The physical and chemical properties of the soil were measured using laboratory tests suggested by the U.S. Salinity Laboratory Staff (1954 and are presented in Table (1). 
Table 1: Physical properties and chemical analyses of the experimental soil

\begin{tabular}{|c|c|c|c|c|c|c|c|c|c|c|}
\hline \multicolumn{4}{|c|}{ Mechanical analysis } & \multirow{2}{*}{\multicolumn{2}{|c|}{ Texture }} & \multirow[t]{2}{*}{ pH } & \multirow[t]{2}{*}{ EC. dS/m } & \multirow{2}{*}{\multicolumn{2}{|c|}{$\begin{array}{c}\mathrm{CaCo}_{3} \\
\%\end{array}$}} & \multirow{2}{*}{$\begin{array}{c}\text { O.M. } \\
\%\end{array}$} \\
\hline Season & Sand\% & Silt\% & Clay\% & & & & & & & \\
\hline $2013 / 2014$ & 90 & 5 & 5 & \multicolumn{2}{|c|}{ sandy } & 7.25 & 5.98 & \multicolumn{2}{|l|}{5.4} & 0.79 \\
\hline $2014 / 2015$ & 90 & 5 & 5 & \multicolumn{2}{|c|}{ sandy } & 7.27 & 6.02 & \multicolumn{2}{|l|}{5.6} & 0.81 \\
\hline \multicolumn{11}{|c|}{ Chemical analysis } \\
\hline \multicolumn{7}{|c|}{ Cations (meq/L) } & \multicolumn{4}{|c|}{ Anions (meq/L) } \\
\hline Season & $\mathbf{N}^{+}$ & $\mathbf{P}^{+}$ & $\mathrm{Ca}^{++}$ & $\mathrm{Mg}^{++}$ & $\mathrm{Na}^{+}$ & $\mathbf{K}^{+}$ & $\mathrm{CO}_{3}^{-}$ & $\mathrm{HCO}_{3}^{-}$ & $\mathrm{CL}^{-}$ & $\mathrm{SO}_{4}^{--}$ \\
\hline $2013 / 2014$ & Traces & 0.38 & 53.75 & 23.71 & 17.0 & 2.19 & Zero & 8.0 & 68.0 & 20.74 \\
\hline $2014 / 2015$ & Traces & 0.42 & 53.75 & 23.79 & 17.2 & 2.13 & Zero & 8.0 & 68.0 & 20.78 \\
\hline
\end{tabular}

Garlic cultivar: Chinese cultivar was tested in by Chaovanalikit and Wrolstad (2004). The

this study. This cultivar is characterized by its big cloves, easy peer; the cloves have shiny white skin with purple vertical lines.

\section{Source of the bio-stimulants}

Halex-2 is a biofertilizer made up of a mixture of growth promoting of non-symbiotic $\mathrm{N}$-fixing bacteria of genera Azospirillum, Azotobacterand Klebsiella. Halex-2 was kindly provided by the Biofertilization Unit, Department of Plant Pathology, The Faculty of Agriculture, Alexandria University. Egypt. Cloves of the tested cultivar "Chinese" were inoculated by soaking in cell suspension of the Halex-2 containing 5\% Arabic gum, at the rate of $400 \mathrm{~g} /$ fed. for half an hour according to the recommendation of the above mentioned Department. The inoculation with Halex-2 was repeated three weeks later as side dressing beside seedlings (Ghoneim, 2005).

Yeast extract:- The brewer's yeast (Saccharomyces cerevisiae) was dissolved in water. Sugars were added to the yeast at a ratio of $1: 1$. The extract was kept for 24 hours in a warm place for reproduction, as explained by Morsi et al. (2008).

\section{Data recorded}

Vegetative characters:- Ten randomly plants from each replicate were used to determine each of plant height $(\mathrm{cm})$, number of leaves / plant and leaves fresh weight $(\mathrm{gm})$. The obtained data were averaged and recorded.

Yield and yield components:- garlic yield was calculated for plot area then attributed to the feddan (fed.), where fed. $=4200 \mathrm{~m}^{2}$. A random sample $(10$ bulbs) was taken from each treatment to determine both bulb weight (gm) and number of cloves/bulb.

Bulb quality characteristics:- Ten randomly bulbs were taken from each replicate and used to determine neck thickness $(\mathrm{cm})$, bulb diameter $(\mathrm{cm})$, bulbing ratio $(\%)$, cloves firmness $\left(\mathrm{Kg} / \mathrm{cm}^{2}\right)$ and total phenol content $(\mathrm{mg} / \mathrm{g})$. Bulbing ratio was calculated according to Mann (1952) = Neck diameter $(\mathrm{cm})$ / Bulb diameter $(\mathrm{cm})$. Cloves firmness $\left(\mathrm{Kg} / \mathrm{cm}^{2}\right)$ was measured using fruit pressure tester model FT 327 (3-27 Lbs.), Italy. Total phenolic were determined colorimetrically using Folin Ciocalteureagent at $755 \mathrm{~nm}$ as explained obtained data were averaged and recorded.

Cloves Chemical analysis:- The following chemical elements were analyzed in garlic bulbs: Nitrogen (N), Phosphorus (P) and Potassium (K). Harvested bulbs were dried at $65 \circ \mathrm{C}$ for $72 \mathrm{~h}$ and then ground with a mill. Determination was done as outlined by APHA (2005).

GC-MS analysis:- The GC-MS analysis of the essential oil samples was carried out using gas chromatography-mass spectrometry instrument stands at the Central Lab, National Research Center, Egypt. Most of the compounds were identified using the analytical method: mass spectra (authentic chemicals, Wiley spectral library collection and NSIT library).

Collection of tested plant pathogenic fungi:Fusarium oxysporium 9704AUMC, Alternaria alternate 10301AUMC, were obtained from Mycology Center Assiut University, and were maintained on PDA medium, which served as the test fungi for antifungal activity assay.

Medium:- The PDA medium contained potato (200 $\mathrm{g})$, dextrose (20 g), agar (20 g), and distilled water $(1000 \mathrm{ml})$. The $\mathrm{pH}$ of the medium was adjusted to 5.6 with $1 \mathrm{~N} \mathrm{HCl}$ or $\mathrm{NaOH}$. A $20-\mathrm{ml}$ portion of the medium was added to sterilized Petri dish and prepared as the test agar medium.

Preparation of plant extracts:- Planting materials of garlic bulbs, produced from the growing plants during the second season of this study, were dried in the shade at room temperature, ground using electrical mill into fine powder and extracted by soaking in methanol at the rate of $1: 1(\mathrm{w} / \mathrm{v})$ for 48 hours. The extracts were filtered through cheese cloth under a strong hand pressure and the solvent was dried under vacuum at $60-65 \mathrm{C}^{\circ}$ using a rotary evaporator. The extracted residue was dissolved in dimethyl sulfoxide $(1 \mathrm{mg} / \mathrm{ml})$. The crude extracts were preserved under refrigeration until use (Dawood et al., 2003).

Screening of garlic plant extracts for antifungal activities:- Sixteen plant extracts of garlic bulb (derived from the applied fertilization treatments) were examined for their inhibitory activities against tested phytopathogenic fungi Fusarium oxysporium and Alternaria alternate by using agar diffusion 
technique (Deans and Ritchie, 1987). Dry potato dextrose agar plates were inoculated by spreading spore suspensions of constant fungal inoculum. Wells were made in the inoculated potato dextrose agar plates for plant extracts inoculation $(200 \mu)$. All plates were incubated at $26 \pm 2^{\circ} \mathrm{C}$ for 72 hours. The diameter of inhibition zones was determined for all tested fungi.

Preparing media for evaluation the selected extracts on fungal linear growth:- The media were prepared as $100 \mathrm{ml}$ aliquos in $250 \mathrm{ml}$ Eyrlenmeyer flasks. After autoclaving, the media were amended with different concentrations of plant extract $(0.5 \%$ , $1.5 \%$ and $2.5 \%$ ). The medium was poured in petri dishes and left for solidification. Mycelial discs were cut out from the growing edges of the tested fungal colonies and transferred separately to these plates. Control plates were without plant extract. Triplicate dishes were used for each treatment. All dishes were incubated at $26 \pm 2 \mathrm{C}^{\circ}$ during the whole experimental period. Daily measurement of linear growth was carried out (El-Morsy, 1993).The inhibition rates were calculated according to formula by Deans and Svoboda (1990):

$\mathrm{I}=\mathrm{C}-\mathrm{T} / \mathrm{C} \times 100$

Where; $\mathrm{I}=$ percent mycelial inhibition, $\mathrm{C}=$ mean colony diameter of control sets, and $\mathrm{T}=$ mean colony diameter of treatment sets.

\section{Experimental design and statistical analysis}

The experimental layout was presented as a splitsplit-plot in a randomized complete blocks design (R.C.B.D), with three replicates. Two sources of nitrogen fertilizers were assigned in the main plots, two rates of nitrogen units were assigned to the subplots and four bio-stimulants which were, randomly, distributed in the sub-sub-plots. Collected data of sixteen samples of garlic extracts were layout as a randomized complete design (R.C.D). Collected data of the experiments were, statistically, analyzed using the analysis of variance method. Comparisons among the means of different treatments were done, using least significant differences (L.S.D) test procedure at $p=0.05$ level of probability, as illustrated by Snedecor and Cochran (1980). Computation was done using Co-Stat software program (2004).

\section{RESULTS AND DISCUSSION}

Main effects of the studied treatments on the garlic vegetative measurements

The studied vegetative characters were significantly affected with nitrogen fertilization source only during the second season of this experiment (Table, 2). The recorded data divulged that fertilization garlic plants with ammonium nitrate fertilizer; led to enhance the vegetative traits compared to the fertilization with ammonium sulphate fertilizer. This result could be attributed to its easiest solubility in water compared to ammonium sulphate fertilizer. The data showed that ammonium nitrate fertilizer exhibited the best results. The results showed that adding $120 \mathrm{~kg} \mathrm{~N} /$ fed. significantly gave rise to the mean highest values for the vegetative measurements. Generally, inoculation of bio-stimulants to the growing garlic plants led to better results for the vegetative traits compared to non-inoculated one. The highest mean values were obtained when the growing garlic plants inoculated with both "Halex-2" + yeast extract during both seasons of this experiment (Table, 2). Leaves fresh weight character, was significantly, affected with bio-stimulants treatments during the first season only.

Table 2: Averages of vegetative growth characters of Chinese garlic as affected by nitrogenous sources, its rate and bio-stimulants during the seasons of 2013/2014 and 2014/2015.

\begin{tabular}{|c|c|c|c|c|c|c|}
\hline \multirow[b]{2}{*}{ Treatments } & \multicolumn{3}{|c|}{ Season 2013/2014 } & \multicolumn{3}{|c|}{ Season 2014/2015 } \\
\hline & $\begin{array}{l}\text { Plant } \\
\text { height } \\
\text { (cm) }\end{array}$ & $\begin{array}{c}\text { No. of } \\
\text { leaves / } \\
\text { plant } \\
\end{array}$ & $\begin{array}{c}\text { Leaves } \\
\text { fresh } \\
\text { weight (g) } \\
\end{array}$ & $\begin{array}{c}\text { Plant } \\
\text { height } \\
\text { (cm) }\end{array}$ & $\begin{array}{c}\text { No. of } \\
\text { leaves / } \\
\text { plant } \\
\end{array}$ & $\begin{array}{c}\text { Leaves } \\
\text { fresh } \\
\text { weight }(g) \\
\end{array}$ \\
\hline & \multicolumn{6}{|c|}{ Nitrogen source } \\
\hline Ammonium nitrate & $50.03 \mathrm{a}$ & $9.19 \mathrm{a}$ & $21.45 \mathrm{a}$ & $54.54 \mathrm{a}$ & $8.46 \mathrm{a}$ & $19.22 \mathrm{a}$ \\
\hline \multirow[t]{2}{*}{ Ammonium sulphate } & $48.64 \mathrm{a}$ & $8.96 \mathrm{a}$ & $20.63 \mathrm{a}$ & $47.55 b$ & $7.03 \mathrm{~b}$ & $14.64 \mathrm{~b}$ \\
\hline & \multicolumn{6}{|c|}{ Nitrogen rate } \\
\hline $120 \mathrm{Kg}$ nitrogen $/$ fed. & $53.71 \mathrm{a}$ & $9.61 \mathrm{a}$ & $24.66 \mathrm{a}$ & $57.46 \mathrm{a}$ & $8.41 \mathrm{a}$ & $18.65 \mathrm{a}$ \\
\hline \multirow[t]{2}{*}{$90 \mathrm{Kg}$ nitrogen /fed. } & $44.96 \mathrm{~b}$ & $8.55 b$ & $17.42 \mathrm{~b}$ & $44.63 b$ & $7.09 \mathrm{~b}$ & $15.21 \mathrm{~b}$ \\
\hline & \multicolumn{6}{|c|}{ Bio-stimulants } \\
\hline Without & $44.93 \mathrm{c}$ & $8.40 \mathrm{c}$ & $17.67 \mathrm{c}$ & $46.19 d$ & $7.08 \mathrm{~d}$ & $16.07 \mathrm{a}$ \\
\hline Halex-2 (H) & $51.00 \mathrm{ab}$ & $9.19 \mathrm{~b}$ & $21.35 b$ & $52.85 b$ & $8.02 \mathrm{~b}$ & $17.14 \mathrm{a}$ \\
\hline Yeast extract $(\mathrm{Y})$ & $49.39 \mathrm{~b}$ & $9.03 \mathrm{~b}$ & $21.43 b$ & $50.07 \mathrm{c}$ & $7.52 \mathrm{c}$ & $16.68 \mathrm{a}$ \\
\hline Halex-2+ Yeast extract & $52.01 \mathrm{a}$ & $9.69 a$ & $23.72 \mathrm{a}$ & $55.08 \mathrm{a}$ & $8.37 \mathrm{a}$ & $17.84 \mathrm{a}$ \\
\hline
\end{tabular}

Means having an alphabetical letter in common, within a comparable group of means, do not significantly differ, using least significant differences test procedure (L.S.D) at $p=0.05$ level of probability. 
The positive effects of tested bio-stimulants on the vegetative characters were mainly due to the role of Halex-2 in increasing the availability of $\mathrm{N}$ to plant absorption and containing yeast cytokinins, enzymes, vitamins, minerals and amino acids which have positive role on cell division and elongation, nucleic acid synthesis, protein and chlorophyll formation (Khedr and Farid, 2002, Mahmoud, 2001).

El-zohiri and Abdou (2009) reported that increasing the nitrogen fertilizer level from 60 up to $120 \mathrm{~kg}-\mathrm{N} / \mathrm{fed}$., significantly, increased all the studied vegetative growth characters of garlic "Seds $40 \mathrm{cv}$; i.e., plant height, number of leaves , fresh and dry matter of leaves. Meanwhile, Zaman et al. (2011) reported that the increase in plant height trait due to nitrogen application indicates a positive role of nitrogen on plant growth and the soil was deficient in nitrogen. Herein, Naruka (2000) explained that availability of nitrogen is of prime importance for growing plants as it is a major and indispensable source of protein and nucleic acid molecules, since nitrogen is an essential part of chlorophyll molecules, which are responsible for photosynthesis. The same author added that using $\mathrm{N}$ fertilizer helps to increase production and is a somewhat quick method for reaching maximum yields. These results are in accordance with that obtained by Naruka (2000); Naruka and Dhaka (2001); Yadav (2003); Banafar and Gupta (2005); Naruka et al. (2005). The findings of Table (2) are in accordance with those obtained by Abdel-Razzak and El-Sharkawy (2013) who reported that the biofertilizer "Halex-2" has a positive effect on increasing the availability of $\mathrm{N}$ to plant absorption which in turn increases the vegetative growth of garlic plants. Similar findings were recorded by ElDesuki et al. (2006); Yaso et al. (2007) on onion. The results of Shafeek et al. (2015) on onion; cleared that bio-stimulants showed positively influence on the vegetative growth and total production and its quality.

Effects of the first-order interactions of studied treatments on garlic vegetative measurements

The results of Table (3) appeared that all the firstorder interactions possessed significant differences for the studied vegetative traits during both seasons of the study. In this respect, adding $120 \mathrm{Kg}$ nitrogen per feddan in form of ammonium nitrate; gave the highest and significant results for the studied vegetative characters.

Table 3: Averages of vegetative growth characters of Chinese garlic as affected by the first-order interactions between nitrogenous sources, its rate and bio-stimulants during the seasons of 2013/2014 and 2014/2015

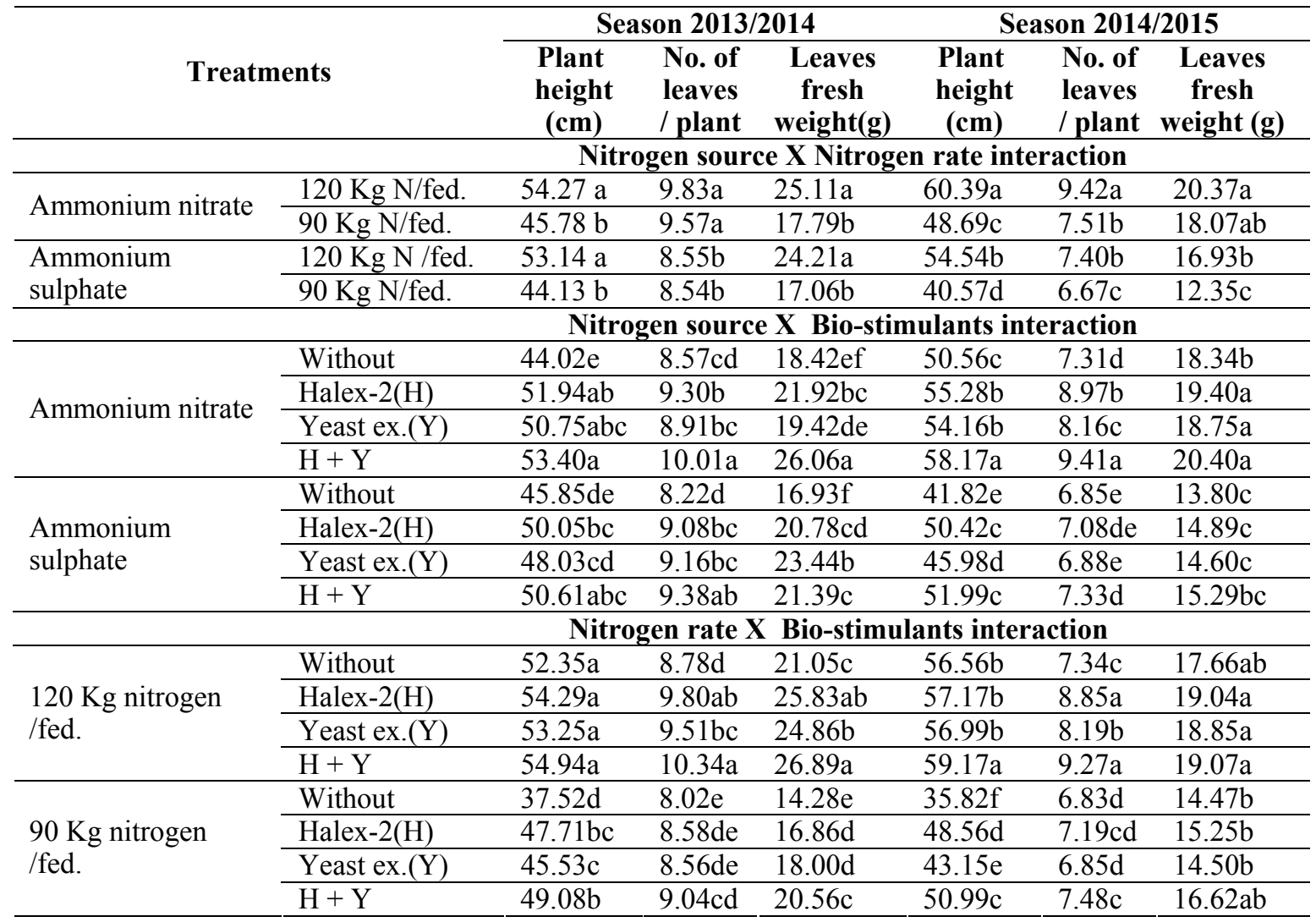

Means having an alphabetical letter in common, within a comparable group of means, do not significantly differ, using least significant differences test procedure (L.S.D) at $p=0.05$ level of probability. 
The data of the interaction between nitrogen source and bio-stimulants showed that inoculation growing garlic plants with Halex-2 + yeast extract, significantly, encouraged the vegetative growth of garlic plants during the growing seasons of the research (Table, 3). The interaction between nitrogen rate and biostimulants show that the vegetative measurements recorded the highest values when garlic plants were fertilized with $120 \mathrm{Kg}$ nitrogen / Fed. combined with Halex-2 or with bio-stimulants (Halex-2 + yeast extract). Generally, the data of the Table (3) clearly show benefit effects of the bio-stimulants on the vegetative growth of garlic plants. These positive effects were achieved by significant increases in the studied vegetative traits; plant height, No. of leaves per plant, and leaves fresh weight. This can be attributed to the role of bio-stimulants in enhancing both plant nutrients uptake and plant metabolism processes, hence gain in accumulation of proteins, carbohydrates and vitamins. This explanation is in accordance with Shalaby and El-Ramady (2014) and Ahmed (2015) on garlic crop.

Effects of the second-order interactions of studied treatments on garlic vegetative measurements

The data of the interaction between nitrogen source $\mathrm{x}$ nitrogen rate $\mathrm{x}$ bio-stimulants are presented in Table (4). There were highly significant differences among the tested fertilization treatments regarding all the vegetative characters during both growing seasons. The fertilization treatment No. 4 (composed of $120 \mathrm{~kg} \mathrm{~N} /$ fed. at the form of ammonium nitrate + Halex-2 + yeast extract) gave the highest mean values for all studied vegetative characters during both seasons; as shown in Table (4). Plant height character, there were no significant differences among the fertilization treatments No. 4 and No.1,2,3,9,10, 11 and 12 during the first season. Meanwhile, data showed that there were no significant differences between the previous treatments (No. 4) and No.2 (120 kg nitrogen /fed. at the form of ammonium nitrate + Halex-2) during the second season. The highest values for number of leaves per plant and leaves fresh weight traits were conjoined with the treatment No. 4 with insignificant differences values with the fertilization treatments No. 1,2,10,11 and 12 for number of leaves per plant during the first season. The results of the second season showed that there were no significant differences between the treatment No. 4 and the treatments No. 2 for the number of leaves per plant trait. The data of the second season showed that there were insignificant differences among the eleven fertilization treatments (No. 1, 2,3,4,5,6,7,8, 10, 11 and 12) for leaves fresh weight character. Generally, it could be concluded that the potent treatment of $120 \mathrm{~kg} \mathrm{~N}$ per fed. at the form of ammonium nitrate + Halex-2 + yeast extract; possessed, highest mean values for all the tested vegetative traits which means that this treatment of fertilization enhanced growth attributes of garlic plants.

Table 4: Averages of vegetative growth characters of Chinese garlic as affected by the second-order interactions between nitrogenous sources, its rate and bio-stimulants during the seasons of 2013/2014 and 2014/2015

\begin{tabular}{|c|c|c|c|c|c|c|c|}
\hline \multirow{2}{*}{\multicolumn{2}{|c|}{ Treatments }} & \multicolumn{3}{|c|}{ Season 2013/2014 } & \multicolumn{3}{|c|}{ Season $2014 / 2015$} \\
\hline & & Plant & & Leaves fresh & Plant & & Leaves fresh \\
\hline & & \multicolumn{6}{|c|}{ Nitrogen source $X$ Nitrogen rate $X$ Bio-stimulants interaction } \\
\hline \multirow{4}{*}{ 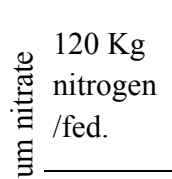 } & 1- Without & $52.25 \mathrm{abcd}$ & $9 \mathrm{abc}$ & 21.39def & $59.00 \mathrm{~b}$ & $7.45 \mathrm{def}$ & $19.33 \mathrm{ab}$ \\
\hline & 2- Halex-2(H) & $54.35 \mathrm{ab}$ & $9.57 \mathrm{a}$ & $26.33 b$ & $60.78 \mathrm{ab}$ & $10.4 \mathrm{a}$ & $21.00 \mathrm{a}$ \\
\hline & 3- Yeast ex.(Y) & $53.84 \mathrm{abc}$ & 7.73def & $22.17 \mathrm{de}$ & $59.45 \mathrm{~b}$ & $9.1 \mathrm{~b}$ & $20.10 \mathrm{ab}$ \\
\hline & 4- $\mathrm{H}+\mathrm{Y}$ & $56.66 \mathrm{a}$ & $9.78 \mathrm{a}$ & $30.56 \mathrm{a}$ & $62.33 \mathrm{a}$ & $10.73 \mathrm{a}$ & $21.06 \mathrm{a}$ \\
\hline \multirow{4}{*}{$\begin{array}{ll} & \\
& 90 \mathrm{Kg} \\
\text { 妾 } & \text { nitrogen } \\
& / \text { fed. }\end{array}$} & 5- Without & $35.79 \mathrm{~h}$ & $7.03 \mathrm{fgh}$ & $15.44 \mathrm{hi}$ & $42.11 \mathrm{e}$ & $7.18 \mathrm{ef}$ & 17.34abcd \\
\hline & 6- Halex-2(H) & $49.54 \mathrm{cde}$ & $8.49 \mathrm{bcd}$ & $17.50 \mathrm{gh}$ & $49.78 \mathrm{~d}$ & $7.53 \mathrm{cde}$ & $17.79 \mathrm{abc}$ \\
\hline & 7- Yeast ex.(Y) & $47.66 \mathrm{ef}$ & $7.18 \mathrm{fg}$ & $16.67 \mathrm{~h}$ & $48.88 \mathrm{~d}$ & 7.22def & $17.40 \mathrm{abcd}$ \\
\hline & 8- $\mathrm{H}+\mathrm{Y}$ & $50.14 \mathrm{bcde}$ & $6.52 \mathrm{gh}$ & $21.55 \mathrm{def}$ & $54.00 \mathrm{c}$ & $8.08 \mathrm{c}$ & $19.74 \mathrm{ab}$ \\
\hline \multirow{8}{*}{ 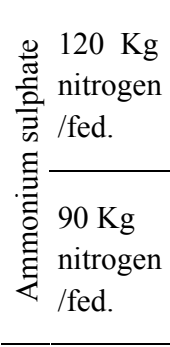 } & 9- Without & $52.45 \mathrm{abc}$ & 7.72def & $20.72 \mathrm{ef}$ & $54.11 \mathrm{c}$ & 7.22def & $15.99 \mathrm{bcde}$ \\
\hline & 10- Halex-2(H) & $54.23 \mathrm{ab}$ & $9.25 \mathrm{ab}$ & $25.33 \mathrm{bc}$ & $53.5 \mathrm{c}$ & 7.30def & 17.07abcd \\
\hline & 11- Yeast ex.(Y) & $52.66 \mathrm{abc}$ & $8.91 \mathrm{abc}$ & $27.56 \mathrm{~b}$ & $54.53 \mathrm{c}$ & $7.28 \mathrm{def}$ & $17.60 \mathrm{abc}$ \\
\hline & 12- $\mathrm{H}+\mathrm{Y}$ & $53.21 \mathrm{abc}$ & $9.5 \mathrm{a}$ & $23.22 \mathrm{~cd}$ & $56.00 \mathrm{c}$ & $7.80 \mathrm{~cd}$ & 17.07abcd \\
\hline & 13- Without & $39.24 \mathrm{gh}$ & $6.21 \mathrm{~h}$ & $13.11 \mathrm{i}$ & $29.52 \mathrm{~g}$ & $6.47 \mathrm{~g}$ & $11.60 \mathrm{e}$ \\
\hline & 14- Halex-2(H) & $45.88 \mathrm{ef}$ & 7.44efg & $16.22 \mathrm{~h}$ & $47.33 \mathrm{~d}$ & $6.85 \mathrm{fg}$ & $12.70 \mathrm{de}$ \\
\hline & 15- Yeast ex.(Y) & $43.40 \mathrm{fg}$ & $8.22 \mathrm{cde}$ & $19.33 \mathrm{fg}$ & $37.42 \mathrm{f}$ & $6.47 \mathrm{~g}$ & $11.60 \mathrm{e}$ \\
\hline & 16- $\mathrm{H}+\mathrm{Y}$ & 48.01de & 7.95def & $19.56 \mathrm{fg}$ & $47.98 \mathrm{~d}$ & $6.87 \mathrm{fg}$ & $13.50 \mathrm{cde}$ \\
\hline
\end{tabular}

$\overline{\text { Means having an alphabetical letter in common, within a comparable group of means, do not significantly differ, using }}$ least significant differences test procedure (L.S.D) at $p=0.05$ level of probability. 
The results of Table (4) show that the fertilizer formulations containing Halex-2 and/ or yeast extract gave, In general, better results for the vegetative characters than those treatments that did not include either of them at the same rate and source of nitrogen fertilization. Bio-stimulants able to enhance vegetative growth, mineral nutrient uptake and improve the yielding of many plants (Fayad, 2005; Fathy et al., 2008; Hassan et al., 2008; Mohamed et al., 2010). Many researches proved the benefit role of yeast extract 0 n stimulating the vegetative growth of plants; i.e., Wanas (2002) on faba bean; Wanas (2006) on tomato and Mady (2009) on faba bean. The authors illustrated that yeast extract had favorable influence on the plant metabolism and biological activity through stimulating photosynthetic pigments and enzyme activity which in turn promote the plant vigorous. In addition, bio-stimulants improved antioxidant activity, vitamin $\mathrm{C}$ and raises leaves pigment of vegetables compared to untreated plants. Thus, the application of bio-stimulants could be considered as a good production strategy for obtaining high production of nutritionally valuable vegetables with lower negative effect on the environment (Sažetak, 2011).

Main effects of the studied treatments on garlic productivity and bulb quality characteristics

The results of Table (5) showed that mineral nitrogen fertilizer source had significant effects on garlic yield; yield components and bulb quality characteristics over both growing seasons except for the number of cloves per bulb and bulbing ratio during the first season. The data, clearly, appeared that ammonium nitrate fertilizer; gave higher mean values for most studied characters compared to ammonium sulphate fertilizer except for cloves firmness and phenol content. These results are in accordance with the obtained results of the vegetative characters; where ammonium nitrate led to enhance the vegetative growth of the growing plants more than ammonium sulphate (Table, 2). Bulbing ratio significanly affected with nitrogen rate during the second season only. These findings confirmed that applying adequate source and quantity of nitrogen fertilizer are correlated with intensifying vegetative growth and leading to greater productivity.

Hassan (2015) explained that the increasing happened of neck thickness, bulb diameter and bulbing ratio by increasing nitrogen level might be due to its role in photosynthesis, protein synthesis, cell division and enlargement which are the basal steps of plant growth. In addition, nitrogen plays an important role in the enzyme activity which reflects more products needed in plant growth. Increasing nitrogen rate from $90 \mathrm{~kg}$./fed. up to $120 \mathrm{~kg}$./fed.; led to significant positive effects on garlic productivity and its component characters (Table, 5). The results of ElZohiri and Abdou (2009) concluded that average clove weight, fresh weight of bulb; as well as, total produced yield of garlic were positively affected with increasing nitrogen level from 60 up to $120 \mathrm{~kg} \mathrm{~N} /$ fed. during both growing seasons. Those authors explained that the increments in total yield production as a result of application of the highest level of nitrogen might be due to the increase in average bulb parameters and number of cloves/bulb and the effect of nitrogen on vegetative growth aspects which in turn affected the total production. Similar results and explanations are also reported by Kilgori et al. (2007) on garlic; ElDesuki (2004) and Nasreen et al. (2007) on Onion. Zaman et al. (2011) found that production of maximum bulb yield was detected by the application of nitrogen at $150 \mathrm{~kg} / \mathrm{ha}$. due to production of taller plants with higher number of leaves which in turn leading to increase formation of vegetative structure for nutrient absorption, photosynthesis and subsequence increased production of assimilates to fill the sink which result in increased bulb size and weight.

Further, the results of Table (5) show that inoculation garlic plants with bio-stimulants had significantly positive effects on garlic yield and its component characters; as well as, bulb characteristics except for bulbing ratio during the first season compared with un-inoculated treatment. The results of Ahmed (2015) showed that Bulbing ratio and number of cloves traits were not, significantly, affected with bio-stimulants in both seasons. In this regard, inoculation garlic plants with bio-stimulants (Halex-2 + garlic extract) reflected the highest mean values for most studied characters. Such findings of biostimulants on studied characters could be connected with their positive effects on vegetative measurements which in turn effect on produced bulbs. This positive effect on garlic productivity could be attributed to an increase in mineral absorption by plant and thus an increase in plant contents of vitamins, amino acids and carbohydrates. These findings are in accordance with Shalaby and El-Ramady (2014) and Ahmed (2015) on garlic crop

Effects of the first-order interactions of studied treatments on garlic productivity and bulb quality characteristics

The results of Table (6) clearly exhibited that most studied characters, significantly, affected the first-order interactions except for bulbing ratio. Addition of 120 $\mathrm{kg} \mathrm{N} / \mathrm{fed}$. in the form of ammonium nitrate significantly gave the highest values for garlic yield, yield components, neck thickness and bulb diameter. These results could be conjoined with the previous obtained results where the same treatment enhanced the studied vegetative characters. These results positively affected on garlic crop and therefore on bulb characteristics. Cloves firmness had significantly increased when garlic plants fertilized with $90 \mathrm{~kg}$ $\mathrm{N} /$ fed. in the form of ammonium nitrate. The results generally indicated that increasing the nitrogen rate from 90 up to $120 \mathrm{~kg} \mathrm{~N} /$ fed. negatively affected cloves firmness characteristic. 


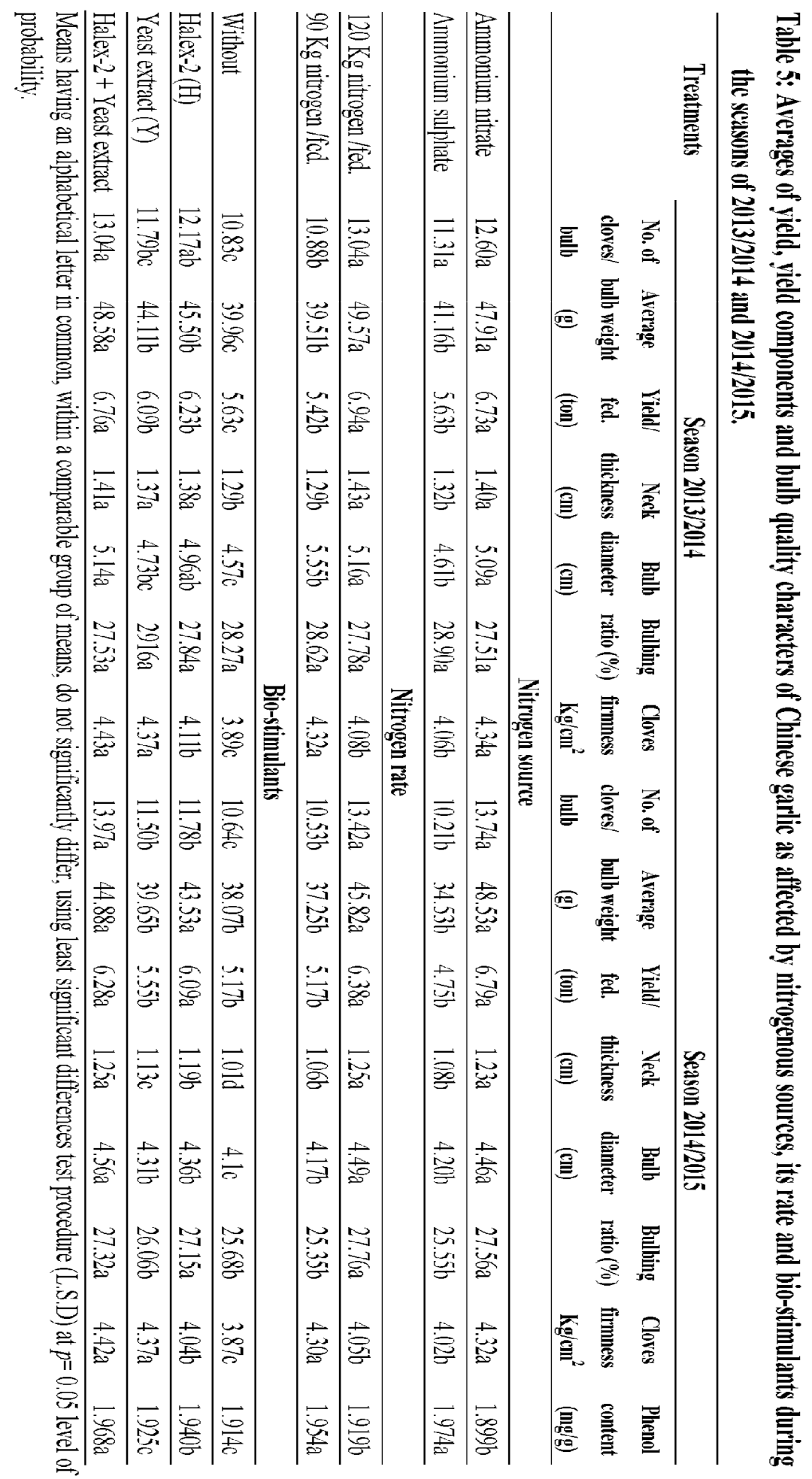


This could be explained by the fact that excess of nitrogen depress calcium uptake which influence on ripening attributes and firmness. Fertilization garlic plants with nitrogenous fertilizers containing sulfur component (mmonium sulphate fertilizer) at the rate of 120 or $90 \mathrm{~kg} \mathrm{~N} / \mathrm{fed}$. had significantly positive effects on increasing phenol content compared with the fertilization with ammonium nitrate fertilizer. This result is in harmony with the previously obtained result that in Table (5) and the explanation of Farooqui et al. (2009) in relation to the role of sulfur element on the active substances in garlic.

The results of the interaction between nitrogen source $\mathrm{x}$ bio-stimulants showed that inoculation growing garlic plants with bio-stimulants generally increased the mean values of garlic yield, its component characters and bulb quality characteristics except for bulbing ratio (Table, 6). The presented data showed that combining ammonium nitrate fertilizer with bio-stimulants (Halex-2 + yeast extract) possessed the highest mean values for garlic yield and yield component characters. Same trend of results were also obtained with bulb quality characteristics; where, neck thickness and bulb diameter gave the highest values with combining ammonium nitrate fertilizer with biostimulants (Halex-2 + yeast extract) without significant differences with combining ammonium nitrate with each of Halex-2 or yeast extract during the first season and combining ammonium nitrate with halex-2 for neck thickness during the second season (Table, 6). Combining ammonium sulphate fertilizer with yeast extract, significantly, gave the highest values for cloves firmness during the two years of this study (Table, 6). This result confirms the role of yeast extract in its effect on increasing plant roots and then increasing the absorption of elements, especially, the element of calcium, which has a significant impact on the garlic cloves firmness. The combination between ammonium sulphate fertilizer and bio-stimulants (Halex-2 + yeast extract), significantly, gave the highest value for phenol content. The interaction between nitrogen rate $\mathrm{X}$ bio-stimulants showed highly significant effects on No. of cloves/bulb, average bulb weight (g) and garlic yield/fed. (Table, 6). The data cleared that combining $120 \mathrm{~kg} \mathrm{~N} /$ fed. with bio-stimulants (Halex-2 + yeast extract), significantly, possessed the highest mean values for garlic yield and its component characters during both seasons. The obtained results from Table (6) regarding garlic yield and its component characters are highly consistent with the previous results of Table (3). It could conclude that the positive stimulation effects happened for the studied vegetative characters (plant height, No. of leaves/plant and leaves fresh weight) had a significant impact on the garlic productivity.

The combination between ammonium sulphate fertilizer and bio-stimulants (Halex-2 + yeast extract), significantly, gave the highest mean value for phenol content. Data of Table (6) appeared that combining chemical nitrogenous fertilizers at the rate of $120 \mathrm{~kg}$ N/fed. with bio-stimulants (Halex-2 +yeast extract) or with Halex-2 only, significantly, possessed the highest mean values for neck thickness and bulb diameter characteristics during the first season. Same trend of results were, also, obtained where combining chemical nitrogenous fertilizers at the rate of $120 \mathrm{~kg} \mathrm{~N} / \mathrm{fed}$. with bio-stimulants (Halex-2 +yeast extract), significantly, gave the highest mean values during the second season. As for cloves firmness and phenol content, the presented data show that the combination between chemical nitrogenous fertilizers at the rate of $90 \mathrm{~kg} \mathrm{~N} / \mathrm{fed}$. with bio-stimulants (Halex-2 + yeast extract), significantly, gave the highest mean values during the two growing seasons.

Effects of the second-order interactions of studied treatments on garlic productivity and bulb quality characteristics

Interactions of nitrogen sources $\mathrm{x}$ nitrogen rates $\mathrm{x}$ bio-stimulants statistically affected No. of cloves/bulb, average bulb weight, yield per fed. and bulb quality characteristics during the two seasons except for bulbing ratio parameter (Table, 7). The results showed that combined ammonium nitrate X120 kg N/fed. X biostimulants (Halex-2 + yeast extract) resulted highest values for No. of cloves per bulb during the two seasons. The data of average bulb weight and garlic yield showed that combined ammonium nitrate X120 kg N/fed. X biostimulants (Halex-2 + yeast extract) gave highest values without significant differences with combined ammonium nitrate X120 kg N/fed. X Halex-2. Such finding is true during the two experimental seasons. This finding can be linked to previously obtained results for the measured vegetative characters (Table, 4); where, the same two fertilization combinations gave the highest values for the studied vegetative traits; i.e., plant height, number of leaves per plant and leaves fresh weight, which reflected in an increasing garlic yield. This result is in agreement with the findings of Baghalian et al. (2006) and Brewester (2008). The data of Table (7) showed that the fertilization combinations containing bio-stimulants (Halex-2 + Yeast extract) produced, in general, best results for garlic yield which outperformed mostly the combinations that did not contain either or both of them at the same rate and source of nitrogen fertilization.

The data of the second-order interaction (nitrogen source $\mathrm{x}$ nitrogen rate $\mathrm{x}$ bio-stimulants) showed that fertilization combination No. 4, significantly, gave the highest mean values for neck thickness and bulb diameter characteristics during the two growing seasons without significant differences with the combinations No. 2 and 3 during the first season. The results of cloves firmness appeared that fertilization treatments No. 15 and 16, significantly, gave the highest mean values during the two seasons of this study. 


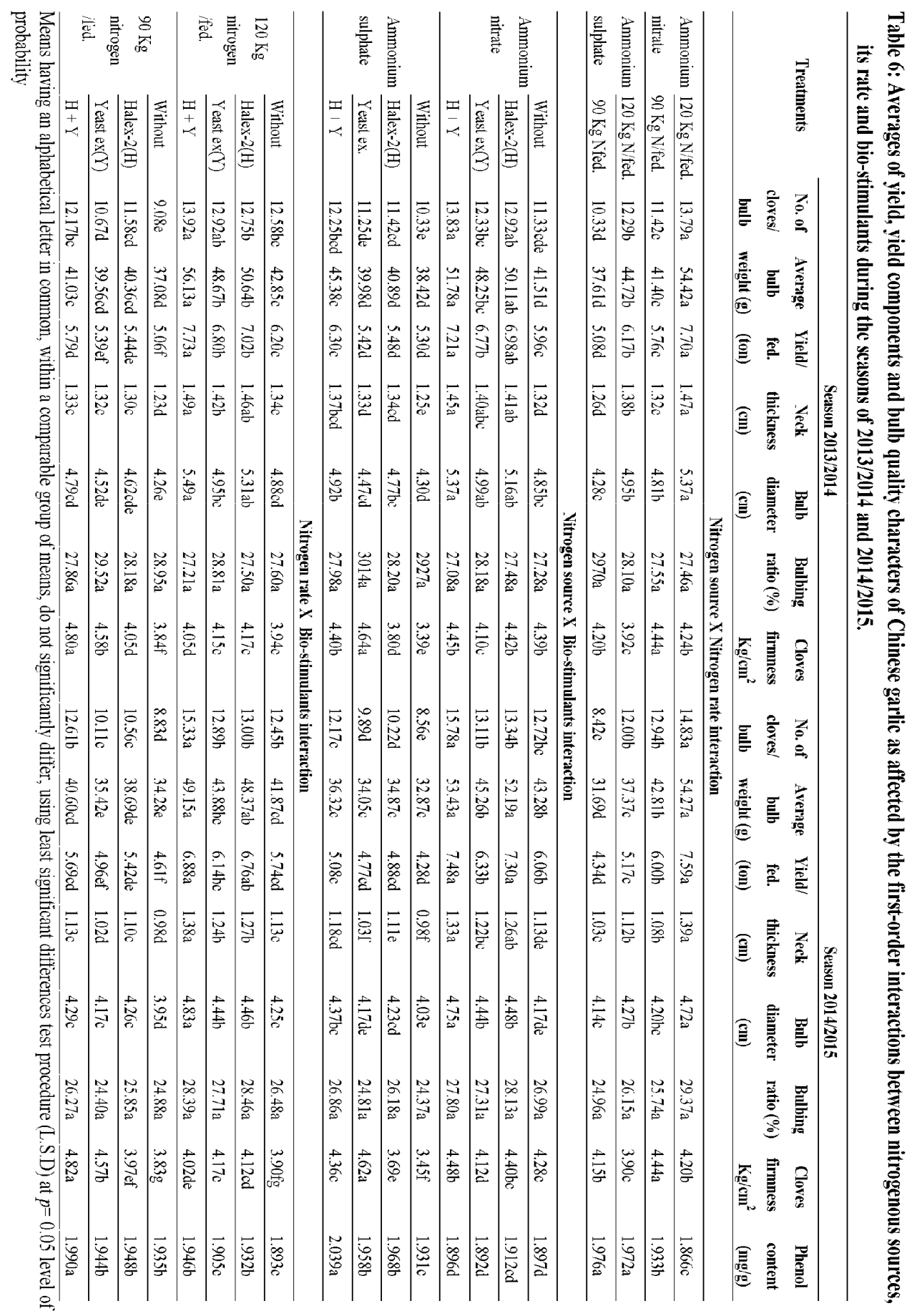




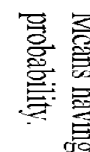

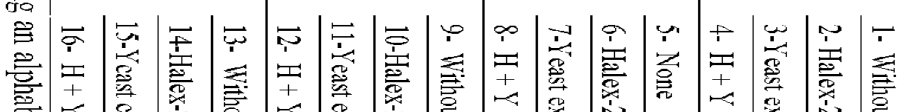

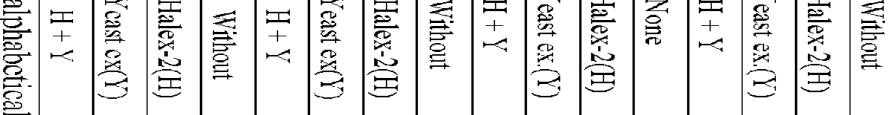

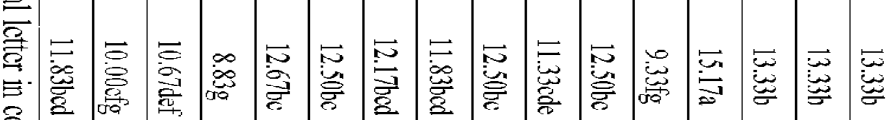

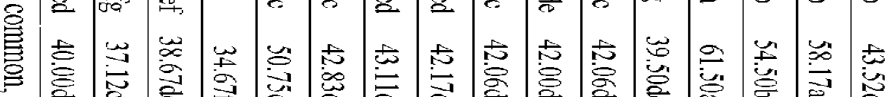

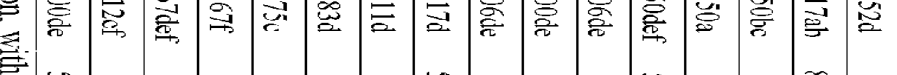

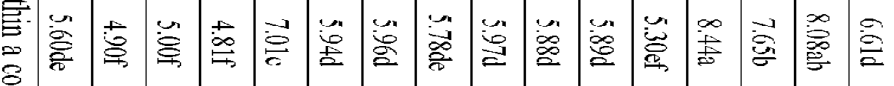

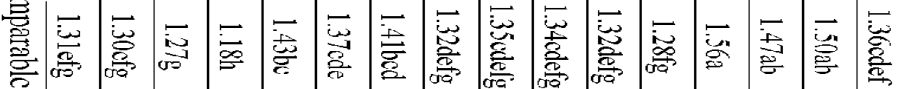

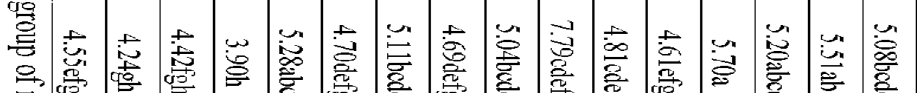
言

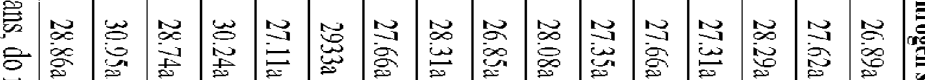

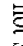

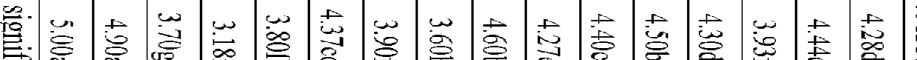
寒

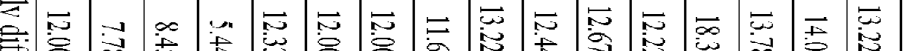

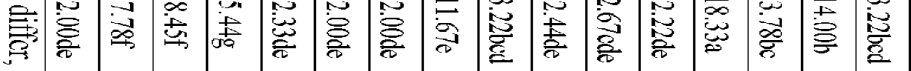

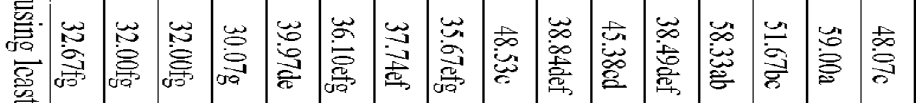

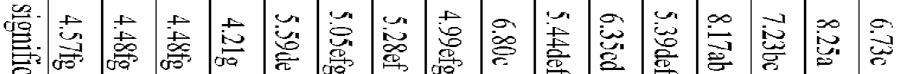

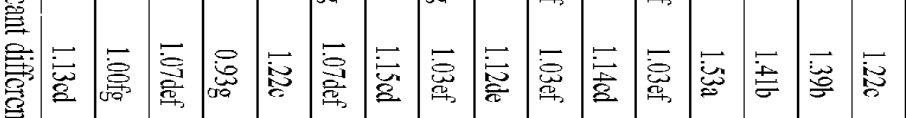

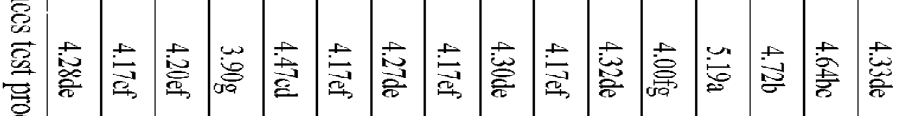

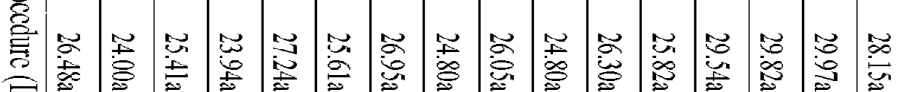

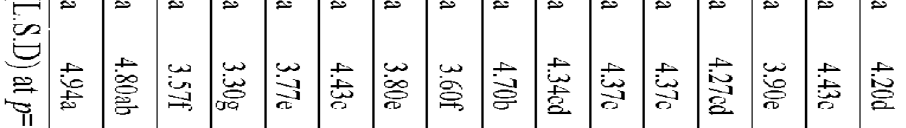

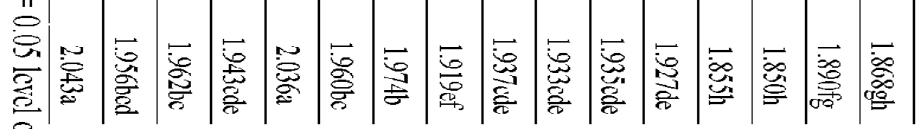

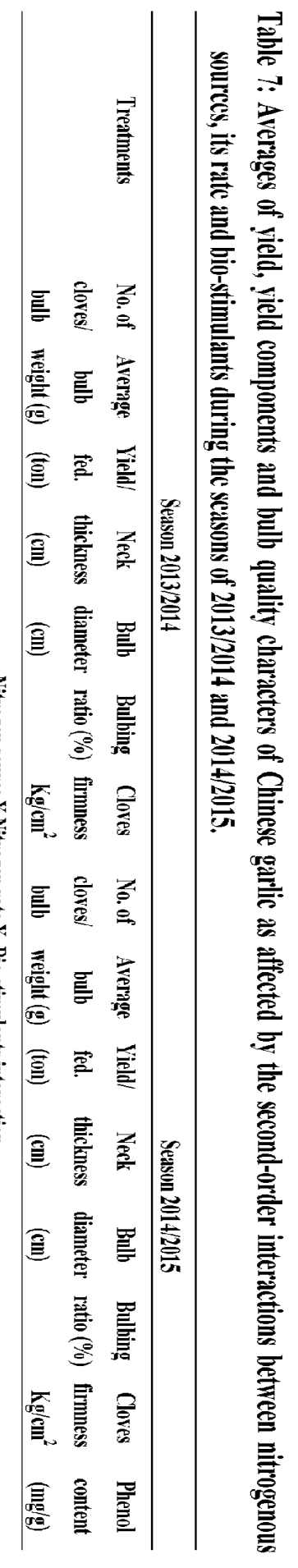


In this respect, Abdel-Razzak and El-Sharkawy (2013) clarified that inoculation of garlic growing plants with Halex-2; caused increases in tonnage bulbs yield during both growing seasons, and clove weight in the first year compared to non-inoculated plants. They explained that the high bulbs yield and clove weight of garlic could be taken place due to the enhancing effects of non-symbiotic $\mathrm{N}_{2}$ fixation bacteria on morphology / or physiology of the root system. Noel et al. (1996) mentioned that the non-symbiotic $\mathrm{N}_{2}$ fixing bacteria; Azotobacter and Azospirillum, created sufficient amounts of Indole acetic acid (IAA), gibberellins (GAs) and cytokinins, as well as, synthesized some vitamins. These products increase the surface area / unit root length and improved the root hair branching with an ultimate lead to increase the uptake of nutrients and adsorption of water from the soil that eventually yield larger and in many cases, more productive plants (Dobbelaere et al., 2001). The role of yeast in influencing the growth of plants, especially vegetables has stated in several reports. El-Ghamriny et al. (1999) reported that the dry bread yeast (Saccharomyces cerevisiae) is a kind of the used bio-fertilizers in soil fertilization or in foliar application on the shoots of vegetable crops. The authors added that dry yeast is a natural bio-substance and it turned out that it has motivational benefits, nutritional and protective roles when it is applied on to vegetable crops under stressful condition because of it contains a lot of hormones, sugars, amino acids and nucleic acids, in addition to numerous of both vitamins and minerals. The results of Fawzy et al. (2012) on onion indicated that, yeast had positive enhancing effects via providing supplemental doses of $\mathrm{N}, \mathrm{P}$ and $\mathrm{K} \%$; as well as, some trace elements components on vegetative growth, yield and its quality; as well as, all chemical compositions compared with the untreated plants.

Data of Table (7) showed that phenol content in garlic bulb was found to be significantly influenced with the tested combination treatments. Data revealed that the

Table 8: Averages of chemical constituents of Chinese garlic bulbs as affected by nitrogenous sources, its rate and bio-stimulants during the season of 2014/2015

\begin{tabular}{lccc}
\hline \multicolumn{1}{c}{ Treatments } & \multicolumn{3}{c}{ Season 2014/2015 } \\
\cline { 2 - 4 } & $\begin{array}{c}\text { Nitrogen } \\
(\mathbf{p p m})\end{array}$ & $\begin{array}{c}\text { Phosphorus } \\
(\mathbf{p p m})\end{array}$ & $\begin{array}{c}\text { Potassium } \\
(\mathbf{p p m})\end{array}$ \\
\hline & & Nitrogen source & \\
\hline Ammonium nitrate & $4.22 \mathrm{a}$ & $2.00 \mathrm{a}$ & $3.38 \mathrm{a}$ \\
\hline Ammonium sulphate & $2.96 \mathrm{~b}$ & $1.93 \mathrm{a}$ & $3.40 \mathrm{a}$ \\
\hline & & Nitrogen rate & $3.43 \mathrm{a}$ \\
\hline $120 \mathrm{Kg}$ nitrogen $/$ fed. & $4.94 \mathrm{a}$ & $2.10 \mathrm{a}$ & $3.35 \mathrm{a}$ \\
\hline $90 \mathrm{Kg}$ nitrogen $/$ fed. & $2.24 \mathrm{~b}$ & $1.83 \mathrm{~b}$ & $3.26 \mathrm{~b}$ \\
\hline & & Bio-stimulants & $3.30 \mathrm{~b}$ \\
\hline None & $1.60 \mathrm{~d}$ & $1.80 \mathrm{~b}$ & $3.27 \mathrm{~b}$ \\
\hline Halex-2 (H) & $4.31 \mathrm{~b}$ & $1.75 \mathrm{~b}$ & $3.75 \mathrm{a}$ \\
\hline Yeast extract $(Y)$ & $2.48 \mathrm{c}$ & $2.51 \mathrm{a}$ & $1.80 \mathrm{~b}$ \\
\hline
\end{tabular}

Means having an alphabetical letter in common, within a comparable group of means, do not significantly differ, using least significant differences test procedure (L.S.D) at $p=0.05$ level of probability. treatments No. $12(120 \mathrm{~kg}$ nitrogen $/$ fed. at the form of ammonium sulphate + Halex-2 + Yeast extract) and No. $16(90$ nitrogen $\mathrm{kg} / \mathrm{fed}$. at the form of ammonium sulphate + Halex-2 + Yeast extract), significantly, gave the highest mean values for phenol content (Table, 7). The findings showed that the combination treatments with ammonium sulfate fertilizer; generally, gave highest phenol content values in garlic bulbs. This finding might be attributed to sulphur element present in ammonium sulphate fertilizer, which could have a positive effect on the active substances especially phenolic in garlic. The results also showed that the addition of bio-stimulants (Halex-2 + yeast extract) to the ammonium sulphate mineral fertilizer could have a positive role in increasing the proportion of phenol in garlic cloves.

As for cloves firmness, the results of Table (7) showed that the two fertilization combinations; ammonium sulphate $X 90 \mathrm{~kg}$ nitrogen $X$ biostimulants (Halex-2 + yeast extract) and ammonium sulphate $\mathrm{X} \quad 90 \mathrm{~kg}$ nitrogen $\mathrm{X}$ yeast extract, significantly, gave the highest mean values. These high values given for garlic firmness means that these two fertilization combinations could be desirable for increasing the storability of garlic crop.

\section{ents on chical constituents of garlic bulbs}

The data presented in Table (8) showed that nitrogen content had, significantly, affected by nitrogen source. The highest mean value for nitrogen was obtained when ammonium nitrate fertilizer was applied. Both of phosphorus and potassium contents did not affect by nitrogen source treatments (Table, 8 ). Nitrogen rate appeared to have a role in influencing garlic bulb contents of nitrogen and phosphorus. Increasing nitrogen rate from $90 \mathrm{~kg} / \mathrm{fed}$. up to 120 $\mathrm{kg} /$ fed.; seemed to have a significant positive effect on increasing the garlic bulb contents of both nitrogen and phosphorus. 
Meanwhile, potassium content did not affect with increasing nitrogen fertilization rate upon raising from $90 \mathrm{~kg} / \mathrm{fed}$ up to $120 \mathrm{~kg} / \mathrm{Fed}$. Likewise, the gained results showed that bio-stimulants, also, had significant effects on $\mathrm{N}, \mathrm{P}$, and $\mathrm{K}$ contents respectively. The highest mean values of nitrogen and potassium contents were obtained upon inoculation garlic plants with the combination of both Halex-2 + yeast extract. On the other hand, phosphorus possessed the highest mean value due to yeast extract treatment. These positive effects of bio-stimulants on mineral constituents might be attributed to the role of Halex-2 in increasing nitrogen uptake by plant and the effect of yeast extract because its high contents of carbohydrates, amino acids, sugars, fatty acids, proteins, hormones, macro and micro- nutrients (Khedr and Farid, 2002).

Effects of the first-order interactions on chemical constituents of garlic bulbs

The highest level of total nitrogen content of garlic cloves was obtained due to the combination between ammonium nitrate fertilizer and of $120 \mathrm{~kg} \mathrm{~N} / \mathrm{Fed}$. The highest values of phosphorus content were obtained owing to the combinations of ammonium nitrate X 120 $\mathrm{kg} \mathrm{N} /$ Fed., and ammonium sulphate X $120 \mathrm{~kg} \mathrm{~N} / \mathrm{Fed}$. without significant differences between them. The interactions between ammonium nitrate X $90 \mathrm{~kg} \mathrm{~N} / \mathrm{Fed}$., and ammonium sulphate X $120 \mathrm{~kg} \mathrm{~N} / \mathrm{Fed}$; possessed the highest levels of potassium, as shown in Table (9). As for the effect of the interaction between nitrogen source and bio-stimulants, it could be shown that combination of ammonium nitrate fertilizer with biostimulants (Halex-2 + yeast extract), significantly, gave the highest value for nitrogen content (Table, 9). On the other extreme, the combinations of ammonium nitrate $\mathrm{X}$ yeast extract, and ammonium sulphate $\mathrm{X}$ yeast extract; produced the highest level of phosphorus content with significant differences among the other tested interactions. The results of potassium content showed that the highest potassium content in garlic cloves were obtained by both interactions of ammonium nitrate $\mathrm{X}$ bio-stimulants (Halex-2 and yeast extract), and ammonium sulphate $X$ bio-stimulants (Halex-2 and yeast extract) without significant differences between them. The interactions of $120 \mathrm{~kg} \mathrm{~N}$. X bio-stimulants $(\mathrm{H}+\mathrm{Y}), 120 \mathrm{~kg} \mathrm{~N}$. X yeast extract and $90 \mathrm{~kg} \mathrm{~N}$. X biostimulants $(\mathrm{H}+\mathrm{Y})$; gave rise to the highest values for nitrogen, phosphorus and potassium, respectively with significant differences among the other tested interactions.

Table 9: Averages of chemical constituents of Chinese garlic bulbs as affected by the first-order interactions between nitrogenous sources, its rate and bio-stimulants during the season of 2014/2015

\begin{tabular}{|c|c|c|c|c|}
\hline \multirow{2}{*}{\multicolumn{2}{|c|}{ Treatments }} & \multicolumn{3}{|c|}{ Season 2014/2015 } \\
\hline & & \multirow{2}{*}{$\begin{array}{c}\begin{array}{c}\text { Nitrogen } \\
(p p m)\end{array} \\
\text { Nitrogen }\end{array}$} & \multirow{2}{*}{$\begin{array}{l}\text { Phosphorus } \\
\text { (ppm) }\end{array}$} & \multirow{2}{*}{$\begin{array}{c}\text { Potassium } \\
\text { (ppm) }\end{array}$} \\
\hline & & & & \\
\hline \multirow{2}{*}{ Ammonium nitrate } & $120 \mathrm{Kg} \mathrm{N} / \mathrm{fed}$. & $5.39 \mathrm{a}$ & $2.13 \mathrm{a}$ & $3.23 b$ \\
\hline & $90 \mathrm{Kg} \mathrm{N} / \mathrm{fed}$ & $3.04 \mathrm{c}$ & $1.86 \mathrm{~b}$ & $3.53 \mathrm{a}$ \\
\hline \multirow{2}{*}{ Ammonium sulphate } & $120 \mathrm{Kg} \mathrm{N} / \mathrm{fed}$. & $4.48 b$ & $2.06 \mathrm{a}$ & $3.63 \mathrm{a}$ \\
\hline & $90 \mathrm{Kg} \mathrm{N} /$ fed. & $1.44 \mathrm{~d}$ & $1.81 \mathrm{~b}$ & $3.17 \mathrm{~b}$ \\
\hline \multicolumn{5}{|c|}{ Nitrogen source X Bio-stimulants interaction } \\
\hline \multirow{4}{*}{ Ammonium nitrate } & Without & $1.65 \mathrm{f}$ & $1.91 \mathrm{~b}$ & $3.11 \mathrm{c}$ \\
\hline & Halex-2(H) & $5.85 \mathrm{~b}$ & $1.76 \mathrm{bc}$ & $3.25 \mathrm{bc}$ \\
\hline & Yeast ex.(Y) & $2.28 \mathrm{e}$ & $2.55 \mathrm{a}$ & $3.38 \mathrm{bc}$ \\
\hline & $\mathrm{H}+\mathrm{Y}$ & $7.09 \mathrm{a}$ & $1.77 \mathrm{bc}$ & $3.80 \mathrm{a}$ \\
\hline \multirow{4}{*}{ Ammonium sulphate } & Without & $1.54 \mathrm{~g}$ & $1.70 \mathrm{c}$ & $3.41 \mathrm{~b}$ \\
\hline & Halex-2(H) & $2.76 \mathrm{~d}$ & $1.73 \mathrm{bc}$ & $3.33 \mathrm{bc}$ \\
\hline & Yeast ex.(Y) & $2.68 \mathrm{~d}$ & $2.47 \mathrm{a}$ & $3.15 \mathrm{bc}$ \\
\hline & $\mathrm{H}+\mathrm{Y}$ & $4.86 \mathrm{c}$ & $1.84 \mathrm{bc}$ & $3.70 \mathrm{a}$ \\
\hline \multicolumn{5}{|c|}{ Nitrogen rate $X$ Bio-stimulants interaction } \\
\hline \multirow{4}{*}{$120 \mathrm{Kg}$ nitrogen /fed. } & Without & $2.04 \mathrm{f}$ & $1.87 \mathrm{~cd}$ & $3.55 \mathrm{~b}$ \\
\hline & Halex-2(H) & $5.93 b$ & $1.90 \mathrm{~cd}$ & $3.55 \mathrm{~b}$ \\
\hline & Yeast ex.(Y) & $3.48 \mathrm{~d}$ & $2.63 \mathrm{a}$ & $3.24 \mathrm{cde}$ \\
\hline & $\mathrm{H}+\mathrm{Y}$ & $8.29 \mathrm{a}$ & $1.99 \mathrm{c}$ & $3.39 \mathrm{bc}$ \\
\hline \multirow{4}{*}{$90 \mathrm{Kg}$ nitrogen $/ \mathrm{fed}$. } & Without & $1.15 \mathrm{~h}$ & $1.73 \mathrm{de}$ & $2.97 \mathrm{e}$ \\
\hline & Halex-2(H) & $2.68 \mathrm{e}$ & $1.59 \mathrm{e}$ & $3.03 \mathrm{de}$ \\
\hline & Yeast ex.(Y) & $1.48 \mathrm{~g}$ & $2.39 \mathrm{~b}$ & $3.30 \mathrm{bcd}$ \\
\hline & $\mathrm{H}+\mathrm{Y}$ & $3.66 \mathrm{c}$ & $1.62 \mathrm{e}$ & $4.11 \mathrm{a}$ \\
\hline
\end{tabular}

Means having an alphabetical letter in common, within a comparable group of means, do not significantly differ, using least significant differences test procedure (L.S.D) at $p=0.05$ level of probability. 
Effects of the second-order interactions on chemical constituents of garlic bulbs

The results of nitrogen content demonstrated that the combination of ammonium nitrate $\mathrm{X} 120 \mathrm{~kg}$ nitrogen/Fed. $\mathrm{X}$ bio-stimulants $(\mathrm{H}+\mathrm{Y})$; resulted in the highest mean value for nitrogen content followed with the combination ammonium sulphate $X 120 \mathrm{~kg}$ nitrogen/Fed. X bio-stimulants $(\mathrm{H}+\mathrm{Y})$. Phosphorus content was found to be significantly influenced with the fertilization combinations; where, the combination of ammonium nitrate X $120 \mathrm{~kg} \mathrm{~N} /$ fed. X yeast extract possessed the highest value without significant differences among the two combinations of ammonium nitrate X. $90 \mathrm{~kg} \mathrm{~N} /$ fed. X yeast extract and ammonium sulphate X $120 \mathrm{~kg} \mathrm{~N} /$ fed. X yeast extract. Meanwhile, potassium contents appeared; somewhat, significantly affected by fertilization treatments since, fertilization combinations of ammonium nitrate $X 90 \mathrm{~kg} \mathrm{~N} /$ fed. $X$ bio-stimulants $(\mathrm{H}+\mathrm{Y})$ and ammonium sulphate $\mathrm{X} 120 \mathrm{~kg} \mathrm{~N} /$ fed. $\mathrm{X}$ Halex-2; brought about the highest mean values without significant differences between them (Table, 10).

El-Zohiri and Abdou (2009) stated that nitrogen and phosphorus levels were, significantly, increased with increasing nitrogen fertilization from 60 up to $120 \mathrm{~kg} / \mathrm{fed}$. The authors explained that raising nitrogen fertilization led to enhance vegetative growth and in turn increased the uptake of nitrogen element. Similar trend of results was also obtained by El-Desuki (2004) on onion.
Effects of fertilization combination treatments on antifungal activities of garlic extracts against tested phytopathogenic

Antifungal activities of garlic (16 fertilization treatments) extracts are presented in Table (11). The results showed that the most active extract is the one extracted from the planting materials of the growing plants fertilized with ammonium sulphate at the rate of $90 \mathrm{~kg} \mathrm{~N} /$ fed. + Halex-2 + yeast extract against Fusarium oxysporium. The garlic extracts which extracted from planting materials fertilized with ammonium sulphate $(120 \mathrm{~kg} \mathrm{~N} / \mathrm{fed}$.) + Halex-2 + yeast extract and the one extracted from planting materials fertilized by ammonium sulphte $(90 \mathrm{~kg}$ $\mathrm{N} /$ fed.) + Halex-2 + yeast extract possessed the most effective extracts against Alternaria alternate. The results, clearly, showed that the treatment No. 16 significantly gave highest mean values as for Antifungal activities of the tested garlic extracts against the two pathogens of $F$. oxysporium and $A$. alternate without significant differences with the treatment No. 12 for antifungal activities of $A$. alternate. These results could be explained by the fact that these two extracts (No. 12 and 16) which showed the highest efficiency in controlling mycelial growth, having the highest mean values for phenol content; as mentioned before, as well as, its containing sulphur element which exhibit promising fungi static activities and they warrant more consideration as prospective antimicrobials.

Table 10: Averages of chemical constituents of Chinese garlic bulbs as affected by the second-order interactions between nitrogenous sources, its rate and bio-stimulants during the season of 2014/2015

\begin{tabular}{|c|c|c|c|c|c|}
\hline \multirow[b]{2}{*}{ Treatments } & & & \multicolumn{3}{|c|}{ Season 2014/2015 } \\
\hline & & & $\begin{array}{l}\text { Nitrogen } \\
\text { (ppm) }\end{array}$ & $\begin{array}{c}\text { Phosphorus } \\
\text { (ppm) }\end{array}$ & $\begin{array}{c}\text { Potassium } \\
(\mathrm{ppm})\end{array}$ \\
\hline & & \multicolumn{4}{|c|}{ Nitrogen source $X$ Nitrogen rate $X$ Bio-stimulants interaction } \\
\hline \multirow{8}{*}{$\begin{array}{l}\text { Ammonium } \\
\text { nitrate }\end{array}$} & \multirow{4}{*}{$\begin{array}{l}120 \mathrm{Kg} \text { nitrogen } \\
\text { /fed. }\end{array}$} & 1- Without & $2.15 \mathrm{~h}$ & $2.07 \mathrm{def}$ & $3.25 \mathrm{efg}$ \\
\hline & & 2- Halex-2(H) & $7.80 \mathrm{c}$ & $1.96 \mathrm{efg}$ & $3.11 \mathrm{fg}$ \\
\hline & & 3- Yeast ex(Y) & $3.07 \mathrm{~g}$ & $2.68 \mathrm{a}$ & $3.32 \mathrm{efg}$ \\
\hline & & $4-\mathrm{H}+\mathrm{Y}$ & $8.55 \mathrm{a}$ & $1.83 \mathrm{fgh}$ & $3.26 \mathrm{efg}$ \\
\hline & \multirow{4}{*}{$90 \mathrm{Kg}$ nitrogen /fed. } & 5- Without & 1.151 & $1.75 \mathrm{ghi}$ & $2.97 \mathrm{gh}$ \\
\hline & & 6- Halex-2(H) & $3.90 \mathrm{f}$ & $1.56 \mathrm{hi}$ & $3.39 \mathrm{ef}$ \\
\hline & & 7- Yeast ex(Y) & $1.50 \mathrm{k}$ & $2.43 \mathrm{abc}$ & $3.45 \mathrm{def}$ \\
\hline & & $8-\mathrm{H}+\mathrm{Y}$ & $5.63 \mathrm{~d}$ & $1.70 \mathrm{ghi}$ & $4.33 \mathrm{a}$ \\
\hline \multirow{8}{*}{$\begin{array}{l}\text { Ammonium } \\
\text { sulphate }\end{array}$} & \multirow{4}{*}{$\begin{array}{l}120 \mathrm{Kg} \text { nitrogen } \\
\text { /fed. }\end{array}$} & 9- Without & $1.94 \mathrm{i}$ & $1.68 \mathrm{ghi}$ & $3.84 \mathrm{bcd}$ \\
\hline & & 10- Halex-2(H) & $4.06 \mathrm{e}$ & $1.84 \mathrm{fgh}$ & $3.90 \mathrm{ab}$ \\
\hline & & 11- Yeast ex(Y) & $3.90 \mathrm{f}$ & $2.58 \mathrm{ab}$ & $3.16 \mathrm{efg}$ \\
\hline & & $12-\mathrm{H}+\mathrm{Y}$ & $8.02 \mathrm{~b}$ & $2.15 \mathrm{cde}$ & $3.52 \mathrm{cde}$ \\
\hline & \multirow{4}{*}{$90 \mathrm{Kg}$ nitrogen /fed. } & 13- Without & 1.141 & $1.72 \mathrm{ghi}$ & $2.97 \mathrm{gh}$ \\
\hline & & 14- Halex-2(H) & $1.47 \mathrm{k}$ & $1.62 \mathrm{hi}$ & $2.67 \mathrm{~h}$ \\
\hline & & 15- Yeast ex $(Y)$ & $1.50 \mathrm{k}$ & $2.35 \mathrm{bcd}$ & $3.14 \mathrm{efg}$ \\
\hline & & $16-\mathrm{H}+\mathrm{Y}$ & $1.70 \mathrm{j}$ & $1.54 \mathrm{i}$ & $3.89 \mathrm{bc}$ \\
\hline
\end{tabular}

Means having an alphabetical letter in common, within a comparable group of means, do not significantly differ, using least significant differences test procedure (L.S.D) at $p=0.05$ level of probability. 
Table 11: Mean values of inhibition zone of tested plant pathogens as affected by fertilization treatments.

\begin{tabular}{llcc} 
No. & Fertilization treatments & \multicolumn{2}{c}{ plant pathogens } \\
\cline { 2 - 3 } & & $\begin{array}{c}\text { Fusarium } \\
\text { oxysporium }\end{array}$ & $\begin{array}{c}\text { Alternaria } \\
\text { alternate }\end{array}$ \\
\hline 1 & Ammonium nitrate $(120 \mathrm{~kg} \mathrm{~N} / \mathrm{fed})$. & $17.67 \mathrm{c}$ & $22.33 \mathrm{~cd}$ \\
\hline 2 & Ammonium nitrate $(120 \mathrm{~kg} \mathrm{~N} / \mathrm{fed})+$. Halex-2 & $14.33 \mathrm{e}$ & $24.00 \mathrm{bc}$ \\
\hline 3 & Ammonium nitrate $(120 \mathrm{~kg} \mathrm{~N} / \mathrm{fed})+$. yeast extract & $16.33 \mathrm{~d}$ & $20.00 \mathrm{def}$ \\
\hline 4 & Ammonium nitrate $(120 \mathrm{~kg} \mathrm{~N} / \mathrm{fed})+$. Halex-2 + Yeast extract & $19.00 \mathrm{~b}$ & $19.67 \mathrm{ef}$ \\
\hline 5 & Ammonium nitrate $(90 \mathrm{~kg} \mathrm{~N} / \mathrm{fed})$. & $15.67 \mathrm{~d}$ & $20.67 \mathrm{def}$ \\
\hline 6 & Ammonium nitrate $(90 \mathrm{~kg} \mathrm{~N} / \mathrm{fed})+$. Halex-2 & $14.33 \mathrm{e}$ & $25.67 \mathrm{~b}$ \\
\hline 7 & Ammonium nitrate $(90 \mathrm{~kg} \mathrm{~N} / \mathrm{fed})+$. Yeast extract & $13.00 \mathrm{f}$ & $16.33 \mathrm{gh}$ \\
\hline 8 & Ammonium nitrate $(90 \mathrm{~kg} \mathrm{~N} / \mathrm{fed})+$. Halex-2 + Yeast extract & $16.33 \mathrm{~d}$ & $21.67 \mathrm{cde}$ \\
\hline 9 & Ammonium sulphate $(120 \mathrm{~kg} \mathrm{~N} / \mathrm{fed})$. & $16.3 \mathrm{~d}$ & $18.33 \mathrm{fg}$ \\
\hline 10 & Ammonium sulphate $(120 \mathrm{~kg} \mathrm{~N} / \mathrm{fed})+$. Halex-2 & $18.33 \mathrm{bc}$ & $18.67 \mathrm{fg}$ \\
\hline 11 & Ammonium sulphate $(120 \mathrm{~kg} \mathrm{~N} / \mathrm{fed})+$. Yeast extract & $13.33 \mathrm{ef}$ & $18.33 \mathrm{fg}$ \\
\hline 12 & Ammonium sulphate $(120 \mathrm{~kg} \mathrm{~N} / \mathrm{fed})+$. Halex-2 + Yeast extract & $13.33 \mathrm{ef}$ & $28.33 \mathrm{a}$ \\
\hline 13 & Ammonium sulphate $(90 \mathrm{~kg} \mathrm{~N} / \mathrm{fed})$. & $16.33 \mathrm{~d}$ & $18.33 \mathrm{fg}$ \\
\hline 14 & Ammonium sulphate $(90 \mathrm{~kg} \mathrm{~N} / \mathrm{fed})+$. Halex-2 & $16.33 \mathrm{~d}$ & $15.67 \mathrm{~h}$ \\
\hline 15 & Ammonium sulphate $(90 \mathrm{~kg} \mathrm{~N} / \mathrm{fed})+$. Yeast extract & $16.33 \mathrm{~d}$ & $21.67 \mathrm{cde}$ \\
\hline 16 & Ammonium sulphate $(90 \mathrm{~kg} \mathrm{~N} / \mathrm{fed})+$. Halex-2 + Yeast extract & $20.33 \mathrm{a}$ & $28.00 \mathrm{a}$
\end{tabular}

Means having an alphabetical letter in common, within a comparable group of means, do not significantly differ, using least significant differences test procedure (L.S.D) at $p=0.05$ level of probability.

It is known that both phenolic substances and Sulphur have an important role in this regard. Garlic extract have the ability to prevent and manage viral, fungal and even helminthic infections. Newly obtained garlic has been found to impart a significant role in managing food poisoning through killing the causative agents such as E. coli (Shuford et al., 2005; Abdulzahra and Mohammed, 2014).

Effects of the garlic extract concentrations on the percentage of mycelial inhibitions

The results of Table (12) showed that mycelial growth of tested fungi significantly affected with the differences in concentrations of garlic extracts. Concentration of $2.5 \%$ of garlic extract significantly gave the best results for the percentage of mycelial inhibitions against $F$. oxysporium and A.alternate; as well (Table, 12 and Plate, 1). Bagiu et al. (2012) showed that garlic plants, inhibited growth of cells of Candida spp. Allicin and $S$-methyl cysteine sulfoxide isolated and identified were capable of inducing antifungal activity.

Effects of the fertilization treatments on volatile compounds in garlic bulbs

Table (13) shows differences among three garlic extracts in their content of volatile compounds. The results showed that there were significant differences among the three garlic extracts for the assayed volatile compounds content due to fertilization treatments. The results showed that the garlic extracts resulted from fertilization garlic plants with ammonium sulphate $(120 \mathrm{~kg}$ $\mathrm{N} /$ fed.) + Halex-2 + yeast extract or which fertilized with ammonium sulphate (90 kg N/fed.) + Halex-2 + yeast extract, generally, contained higher concentration from volatile compounds, especially, the compounds having Sulphur element.

Table 12: Mean values of mycelial growth and the percentage of inhibitions at different concentrations of most active garlic plant extracts on mycelial growth of tested fungi.

\begin{tabular}{lcccc}
\hline & \multicolumn{3}{c}{ Diameter (mm) of mycelial growth of tested fungi after 6 days } \\
\cline { 2 - 5 } Concentrations & $\begin{array}{c}\text { Ammonium sulphate (90 kg N/fed.) } \\
\text { of garlic extract }\end{array}$ & $\begin{array}{c}\text { Ammonium sulphate (120 kg N/fed.)+ } \\
\text { Halex-2 + Yeast extract against } \\
\text { Fusarium oxysporium }\end{array}$ & $\begin{array}{c}\text { Halex-2 +Yeast extract against } \\
\text { Alternaria alternate }\end{array}$ \\
\cline { 2 - 5 } & $\begin{array}{c}\text { Mean of mycelial } \\
\text { growth (mm) }\end{array}$ & $\begin{array}{c}\text { \% of } \\
\text { inhibition }\end{array}$ & $\begin{array}{c}\text { Mean of mycelial } \\
\text { growth (mm) }\end{array}$ & $\begin{array}{c}\text { \% of } \\
\text { inhibition }\end{array}$ \\
\hline $2.5 \%$ & $16.00 \mathrm{~d}$ & 77.26 & $22.00 \mathrm{~d}$ & 68.22 \\
\hline $1.5 \%$ & $34.33 \mathrm{c}$ & 52.46 & $35.00 \mathrm{c}$ & 4949 \\
\hline $0.5 \%$ & $41.33 \mathrm{~b}$ & 43.42 & $43.00 \mathrm{~b}$ & 37.95 \\
\hline Control & $73.00 \mathrm{a}$ & & $6933 \mathrm{a}$ & \\
\hline
\end{tabular}

Means having an alphabetical letter in common, within a comparable group of means, do not significantly differ, using least significant differences test procedure (L.S.D) at $p=0.05$ level of probability. 


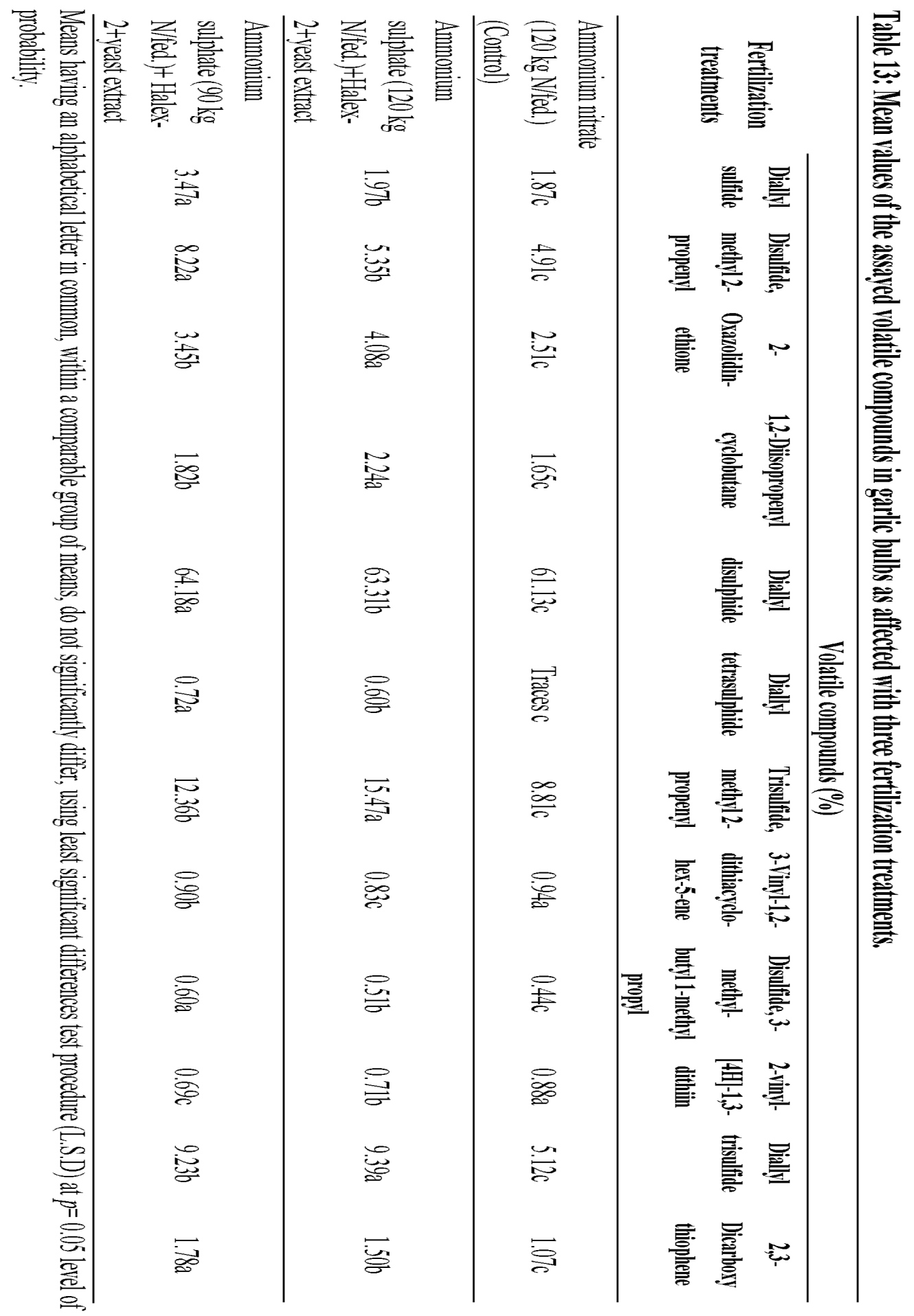




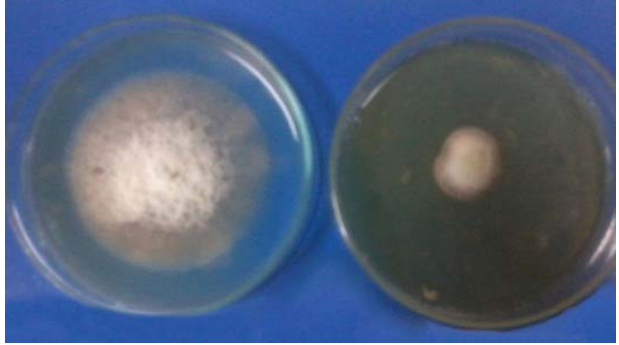

Control

$(2.5 \%)$

Ammonium sulphate (90 kg N/Fed.)+Halex-2 +yeast extract

Fusarium oxysporium

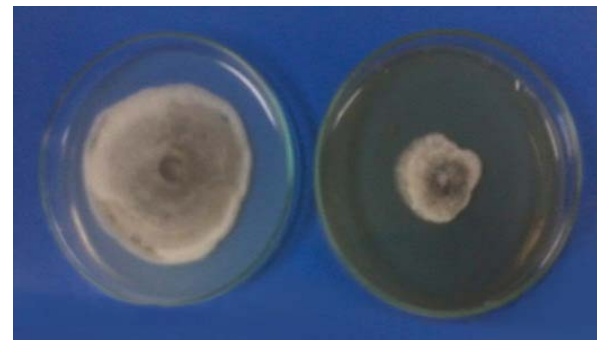

Control $(2.5 \%)$

Ammonium sulphate (120 kg N/Fed.) +Halex-2

+yeast extract

Alternaria alternate

\section{Plate 1: Effect of different concentrations of most active garlic plant extracts on mycelial growth of tested fungi}

The obtained results of Table (13) in addition to the previously results of phenolic contents (Table, 7) might explain the superiority of the two previous fertilization treatments in inhibition of the two studied pathogens.

In particular, diallyl disulfide is the main reason for inhibiting the growth of molds and bacteria by garlic oil (Amonkar and Banerji, 1971). This might be due to damage caused by garlic to the outer surface of the fungal cells together with alterations in the fat content of the cell. It is also probable that garlic may reduce the adhesion of fungal cells to epithelial membrane. Numerous studies indicated that garlic plants have biological and medicinal activities. These activities are mainly because they include high percentages of organo-sulphur compounds content. The sulphur-containing constituting in Allium crops are the S-alk (en) yl-Lcystine sulphoxide (Corzo-Martinez et al., 2007). One of these important organo-sulphur compounds that accumulate in garlic plant extracts has been identified as allicin (Baustista et al., 2005). Garlic extracts are the breakdown products of allicin, including diallyltrisulphide (DATS) and ajoene, which have greater antifungal effects than allicin (Corzo-Marinez et al., 2007).

\section{CONCLUSIONS}

Under the conditions of this study, the results showed that addition of ammonium nitrate fertilizer through the drip irrigation system; gave better results for the studied traits compared to addition of ammonium sulphate fertilizer. Inoculation growing garlic plants with bio-stimulants was found to have positive effective in reducing the mineral nitrogen fertilizer being applied by $25 \%$ as compared with the commonly recommended dose $(120 \mathrm{~kg}$ nitrogen per feddan). Also, the obtained data cleared that garlic productivity could be maximized throughout inoculation garlic plants, which fertilized with $120 \mathrm{~kg}$ nitrogen per fed, with bio-stimulants (Halex-2 + yeast extract). This maximization in garlic productivity reached $27.69 \%$ and $21.40 \%$ during the first and second seasons, respectively compared to the addition of $120 \mathrm{~kg}$ nitrogen of ammonium nitrate fertilizer. Garlic extracts may be an attractive alternative for the use of a natural product to control the fungi that attack economical crops, especially, Fusarium oxysporum and Alternaria alternate, avoiding chemical fungicides application.

\section{REFERENCES}

Abdel-Razzak, H.S. and G.A. El-Sharkawy. 2013. Effect of biofertilizer and humic acid applications on growth, yield, quality and storability of two garlic (Allium sativum L.) cultivars. Asian J. Crop Sci., 5(1): 48-64.

Abdulzahra, D.M. and H.F. Mohammed. 2014. The antibacterial effect of ginger and garlic extracts on some pathogenic bacteria isolated from patients with otitis media. Int. Res. J. Medical. Sci. Vol. 2(5): 1-5.

Abou El-Magd, M.M.; T. El-Shourbagy and S.M. Shehata. 2012. A comparative study on the productivity of four Egyptian garlic cultivars grown under various organic materials in comparison to conventional chemical fertilizer. Aust. J. Basic and Appl. Sci., 6(3): 415-421.

Ahmed, M.E.M. 2015. Response of garlic plants (Allium sativum L.) to foliar application of some bio-stimulants. Egypt. J. Hort. Vol. 42, (1): 613-625.

Agusti, K.T. 1990. Therapeutic and medicinal values of onions and garlic .p: 99-104. In Brewster, J. L and Rabinowitvh, H. D. eds) Onions and Allied Crops. V. 3. CRC Press, Inc. American Public Health Association [APHA]. 2005. Standard Methods for the Examination of 
Water and Wastewater $22^{\text {nd }}$ ed. APHA, Inc. Washington, D.C.

Amonkar, S.V.and A. Banerji. 1971. "Isolation and characterization of larvicidal principle of garlic". Science. 174 (16): 1343-4.

Baghalian, K.; M. R. Naghavi; S. A. Ziai, and H. N. Badi. 2006. "Post-planting evaluation of morphological characters and allicin content in Iranian garlic (Allium sativum L.) ecotypes,". Scientia Horticulturae, 107, (4): 405-410.

Bagiu, R.V.; B. Vlaicu and M. Butnariu. 2012. Chemical composition and in vitro antifungal activity screening of the Allium ursinum L. (Liliaceae), Int. J. Mol. Sci. 13: 1426-1436.

Bajpai, V.K.; T.J. Lee and S.C. Kang. 2009. Chemical composition and in vitro control of agricultural plant pathogens by the essential oil and various extracts of Nandina domestica Thunb. J. Sci. Food Agric. 89:109-116.

Banafar, R.N.S. and N.K.Gupta. 2005. Effect of fertilizer mixture with and without sulphur on quality of onion. In: National Seminar on Agrotechnology, Quality, Processing and Export of Spices, J.N.K.V.V. Jabalpur. pp. 60.

Baustista, D.M.; P. Movahed; A. Hinman; H.E. Axelsson; O. Sterner; E.D. Hogestatt; D. Jullius; S.E. Jordt and P.M. Zygmunt. 2005. Pungent products from garlic activate the sensory ion channel TRPA1. Clinic. and Experi. Pharma. 102(34), 12248-12252.

Brahma, S. and M. N. Yousuf. 2008. Effect of nitrogen and potassium on the growth and yield of garlic. Research Report for 2007-2008. Spices Research Centre, BARI Shibgong, Bogra. pp. 77-8 1 .

Brewester, J. L. 2008. Onions and Other Vegetable Alliums, Crop Production Science in Horticulture, Horticulture Research International, Wellesbourne, UK.

Brewster, J.L. and H.A. Butler. 1989. Effects of nitrogen supply on bulb development in onions (Allepacepa L.) J. Expi. Bot., (40): 1155-1162.

Chaovanalikit, A. and R. E. Wrolstad. 2004. Total anthocyanins and total phenolics of fresh and processed cherries and their antioxidant properties. J. of Food Sci. C73 Vol. 69, Nr. 1.

Copping, L.G. and J.J. Menn. 2000. Biopesticides: a review of their action, applications and efficacy. Pest Manag. Sci. 56: 651-767.

Corzo-Martinez, M; N. Corzo and M. Villamiel. 2007. Biological properties of onions and garlic. Trends in Food Sci. and Techn. 18: 609625.

Co-Stat Software. 2004. User's manual version. Cohort Tusson, Arizona, USA.

Dawood, K. M; Y. M. Shabana; E. A. Fayzalla and E. A. El-Sherbiny. 2003. Search for antifungal compounds of plant origins for biological control of plant diseases: (B) From methanolic plant extracts. J. Agric. Sci. Mans. Vol. 28 (7): 53355349.

Deans, S. G. and G. A. Ritchie. 1987. Antimicrobial properties of plant essential oils. Inter. J. Food Microbiol. 5: 165 - 180.

Deans, S.G. and K.P. Svoboda. 1990. The antimicrobial properties of marjoram (Origanum majorana L.) volatile oil. Flavour Fragr. J. 5, 187- 190 .

Dobbelaere, S.; A. Croonenborghs; A. Thys; D. Ptacek and J. Vanderleyden. 2001. Responses of agronomically important crops to inoculation with Azospirillum. Aust. J. Pl. Physiol., 28: 871-879.

El-Desuki. 2004. Response of onion plants to humic acid and mineral fertilizers application. Annals of Agric. Sci., Moshtohor, 42(4): 1955-1964.

El-Desuki, M.; A.R. Mahmoud and M.H. Hafez. 2006. Response of onion plants to mineral and biofertilizers application. Res. J. Agric. Biolog. Sci., 2: 292-298.

El-Ghamriny, E.A.; H.M.E. Arisha and K.A. Nour. 1999. Studies in tomato flowering fruit set,yield and quality in summer seasons. 1- Spraying with thiamine, ascorbic acid and yeast. Zagazig. J. Agric. Rec., 26(5), 1345-1364.

El-Morsy, A. H. A. 1993. Ecological and physiological studies on fungi present in water and its relation to pollutants in Dakahlia province. M. Sc. Thesis, Botany Department, Faculty of Science, Mansoura University, Egypt.

El-Zohiri, S.S.M. and Y.M. Abdou. 2009. Response of garlic plants to the effect of nitrogen levels and some growth stimulants. Annals of Agric. Sci., Moshtohor, Vol. 47 (3): Ho. 361-374.

Fathy, S.S.; A.M. Moghasy ; M.E. El-Nagar and M.H. Tolba, 2008. Effect of some natural essential oil on cowpea productivity and storability. J. Agric. Sci, Mansoura Univ., 33 (11): 8057-8070.

FAO. 2011. Statistical Year Book. Food and Agriculture Organization (FAO), Rome, Italy.

Farooqui, M.A.; I.S. Naruka; S.S. Rathore; P.P. Singh and R.P.S. Shaktawat. 2009. Effect of nitrogen and sulphur levels on growth and yield of garlic (Allium sativum L.). J. Food Ag-Ind., Special Issue, S18-23.

Fawzy, Z.F.; M.M. Abou El-magd; Yunsheng Li, Zhu Ouyang and A.M. Hoda. 2012. Influence of foliar application by EM "Effective Microorganisms", amino acids and yeast on growth, yield and quality of two cultivars of onion plants under newly reclaimed soil. J. of Agric. Sci.; Vol. 4, No. (11), 26-39.

Fayad, M.H., 2005. Effect of foliar spraying with some plant growth regulators and plant extracts on growth and yield of cucumber plants. PhD, Fac., Agric. Basra Univ., Iraq. 
Ghoneim, I.M. 2005. Effect of biofertilizer types under varying nitrogen levels on vegetative growth, heads yield and quality of globe artichoke (Cynara scolymus, L.). J. Agric. Env. Sci., 4: 1-23.

Gulser, F. 2005. Effects of ammonium sulphate and urea on NO3- and NO2- accumulation, nutrient contents and yield criteria in spinach. J. Sci. Hortic., 106: 330-340.

Hassan, H.A. 2015. Improving Growth and Productivity of two Garlic Cultivars (Allium sativum L.) Grown under Sandy Soil Conditions. Middle East J. of Agri. Res. Vol. 4 (2): 332-346.

Hassan, H.M.; O.K. Ahmed; H.A. El-Shemy and A.S. Afify. 2008. Palm pollen extracts as plant growth substances for banana tissue culture. World J. Agric. Sci., 4(4): 514-520.

Kakara, A.; M.K., Abdullahzai; M. Saleem and S.A.Q. Shah. 2002. Effect of nitrogenous fertilizer on growth and yield of garlic. Asian J. Pl. Sci. 1(5): 544-545.

Kaye, A.D.; B.D. Nossaman; I.N. Ibrahim; C.J. Feng; D.B. Mcnamara; K.C. Agrawal and Kadowitz. 1995. Analysis of responses of allicin, a compound from garlic, in the pulmonary vascular bed of the cat and in the rat. Euro. J. Pharma. 276: 21-26.

Khedr, Z.M.A. and S.Farid. 2002. Response of naturally virus infected tomato plants to yeast extract and phosphoric acid application. Annals of Agric. Sci. Moshtohor. Egypt, 38 (2): 927939.

Kilgori, M.J.; M.D. Magaji and A.I. Yakubu. 2007. Productivity of two garlic (Allium sativum, L.) cultivars as affected by different levels of nitrogen and phosphorus frtilizers in Sokoto, Nigeria. America-Eurasian J. and Environ. Sci., 2(2): 158-162.

Kim, M.K.; G.J. Choi and H.S. Lee. 2003. Fungicidal property of Curcuma longa L. rhizome derived curcumin against phytopathogenic fungi in green house. J Agric. Food Chem 51: 1578-1581.

Lazarević, J.S.; A.S. Đordević; B.K. Zlatković; N.S. Radulović and R.M. Palić. 2011. Chemical composition and antioxidant and antimicrobial activities of essential oil of Allium sphaerocephalon L. subsp. sphaerocephalon (Liliaceae) inflorescences. J. Sci. Food Agric. 91: $322-329$

Mady, M.A. 2009. Effect of foliar application with yeast extract and zink on fruit and yield of faba bean (Vicia faba L).J. Biol. Chem. Environ. Sci., Vol. 4(2): 109-127.

Mahmoud, T. R. 2001. Botanical studies on the growth and germination of magnolia (Magnolia grandiflora L.) plants. M. Sci. Thesis. Fac. of Agric. Moshtohor, Zagazig Univ., Egypt.

Mohamed, A.A.; A.G. El-Emary and H.F. Ali. 2010. Influence of some citrus essential oils on cell viability, glutathione-stransferase and lipid peroxidation in ehrlich ascites carcinoma cell. J. Amer. Sci., 6 (10): 820-826.

Morsi, M.K.; B. El-Magoli; N.T. Saleh; E.M. ElHadidy and H.A. Barakat. 2008. Study of antioxidants and anticancer activity licorice Glycyrrhiza glabra extracts. Egyptian J. Nutr. and Feeds, 2(33): 177-203.

Mudziwa, N. 2010. Yield and quality responses of Egyptian white garlic (Allium sativum L.) and wild garlic (Tulbaghia violacea Harv.) to nitrogen nutrition. M Sc. Thesis, University of Pretoria, South Africa.

Naruka, I.S. 2000. Effect of row spacing and nitrogen fertilization on growth, yield and quality of garlic cultivars. Ph.D. Thesis, RAU, Bikaner.

Naruka, I.S.; P.P. Singh; S.S. Rathore and M. Singh. 2005. Response of garlic (Allium sativumL.) cultivars to nitrogen fertilization and crop geometry on composition of bulb. In: National Seminar on Agro-technology, Quality, Processing and Export of Spices J.N.K.V.V. Jabalpur. pp. 52.

Naruka, I.S. and R.S. Dhaka. 2001. Effect of row spacing and nitrogen fertilization on growth, yield and composition of bulb in garlic (Allium sativumL.) cultivars. J. Spices \& Aromatic Crops, 10 (2): 111-117.

Nasreen, S.; M.M. Haque; M.A. Hossain and A.T.M. Fadid. 2007. Nutrient uptake and yield of onion as influenced by nitrogen and sulphur fertilization. Bangaldesh J. Agric. Res. 32(3): 413-420.

Noel, T.C.; Sheng, C.K. Kost; R.P. Phris and M.E. Hymes.1996. Rhizobium leguminosaium as a plant growth-promoting rhizobacterium: Direct growth promoting of canola and lettuce. Can. J. Microbiol., 42: 279-283.

Sažetak, A., 2011. Greenhouse pepper, natural biostimulants, phenolic content, pigments, vitamin C, antioxidant activity. J. Sci. Food and Agric., 91 (12): 2146-2152.

Shafeek, M.R.; Y.I. Helmy and N. M. Omar. 2015. Use of some bio-stimulants for improving the growth, yield and bulb quality of onion plants(Allium cepa L.) under sandy soil conditions. Middle East J. of App. Sci., 5 (1): 68-75.

Shalaby, T.A. and H. El-Ramady. 2014. Effect of foliar application of bio-stimulants on growth, 
yield, components, and storability of garlic (Allium sativum L.). Aust. J. Crop. Sci., 8 (2): 271-275.

Shuford, J.A.; J.M. Steckelberg and R.Patel. 2005. Effects of fresh garlic extract on C. albicans biofilms, Antimicrob. Agents Chemother. 49 (1): 473 .

Snedecor, G. H. and W. C. Cochran. 1980. Statistical Methods. $7^{\text {th }}$ ed. Iowa State University Press, Ames., Iowa, U.S.A.

Stroke, P.O.; J.P. Potgieter; E. Van Den Heever and J. G. Niederwieser. 2004. Garlic production, guide to garlic production in South Africa, Agricultural Research Council - Vegetable and Ornamental Plant Institute, Roodeplaat, Pretoria.

U.S. Salinity Laboratory Staff. 1954. Diagnosis and improvement of saline and alkali soils. U.S. Dep. Agri. Handbook 60.U.S. Gov. Printing Office, Washington, DC.
Wanas, A.L. 2002. Resonance of faba bean (Vicia fabaL.) plants to seed soaking application with natural yeast and carrot extracts. Annals. Agric. Sci. Moshtohor, 40 (1): 259-278.

Wanas, A.L. 2006.Trails for improving growth and productivity of tomato plants grown in winter. Annals. Agric. Sci. Moshtohor, 44(3):466-471.

Yadav, P.K. 2003. Effect of nitrogen and potassium on growth and yield of garlic(Allium sativumL.) in western Rajasthan. Haryana J. of Horti. Sci., 32 (3-4): 290-291.

Yaso, I.A.; H.S. Abdel-Razzak and M.A. WahabAllah. 2007. Influence of biofertilizer and miniral nitrogen on onion growth yield and quality under calcareous soil conditions. J.Agric. Env. Sci. Alex. Univ., 6(1): 245-264.

Zaman, M.S.; M.A. Hashem; M. Jahiruddin and M.A. Rahim. 2011. Effect of nitrogen for yield maximization of garlic in old Brahmaputra flood plain soil. Bangladesh J. Agric. Res. 36(2): 357-367.

\section{الماذص العري}

\section{تأثير مصادر ومعدلات النشميد النيتروجيف والمهفزات الحيوبة عل إنتلجية الثوه وكماءة مستخلصاته المضاكة انشللات المسببلت المرضية}

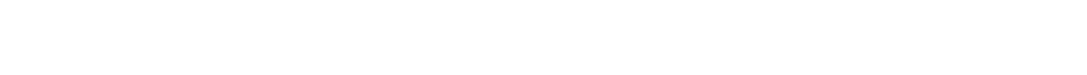

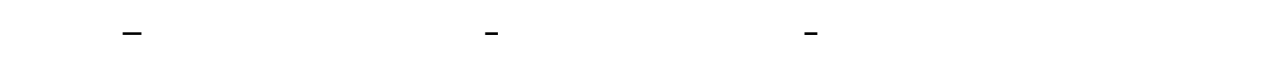

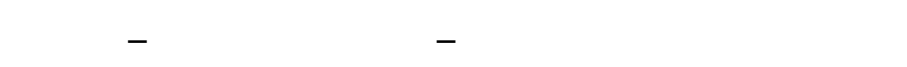

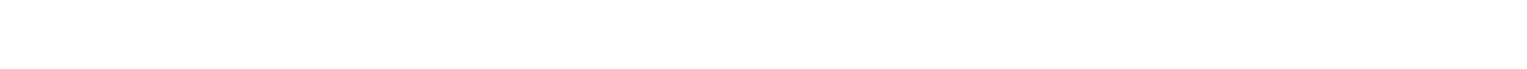

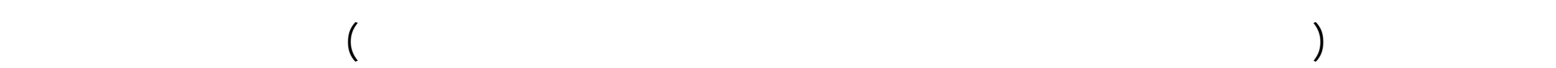

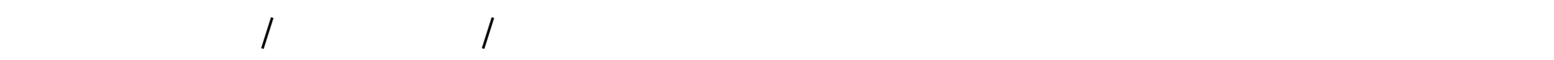
الرى بالتقطط بمدينة للسادات كلحد المنطق المستصلحة حديثا بمزرعة جلمعة مدينة للسادات، محلظة المنوفية، مصر. إثتملت التجربة على المعلملات التالية: - أ - مصادر التسميد المعنف النيتروجيف: -سماد نيترات النشادر سمادسفلت النشادر.ب - معدلات التسميد النيتروجين: - - 9 كجم نيتروجين للفدان - . rا كهم نيتروجين للفدان

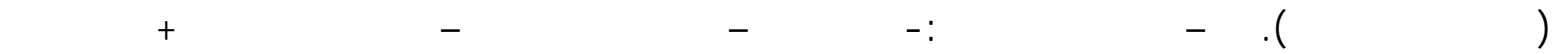
الخميرة معا - بدون محفزات حيوية. صممت التجربة بظلم التطع المشثة المثقة فى قطاعلت كلملة العشوائية حيث مثلت مصادر التسميد النيتروجيف التطع الرئيسية، بينما معدلات التسميد النيتروجيف مثلت التطع المثنقة، أما المحفزات الحيوية فوزعت عثوائيا على التطع المنثقة المنثقة. تهرف الدرلسة اله نقليل إستخدلم الأسمدة الكيميائية

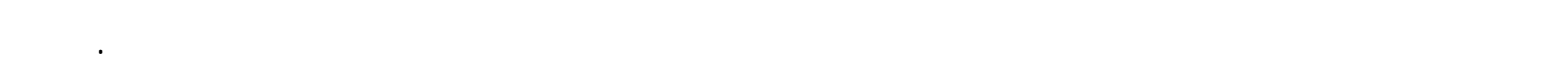


أهتمت هذه التجربة بتحديد الأنشطة المضادة للنطريك من المستخلصت النباتية الملٔخونة من محصول رؤوس الثوم. قم درلسة هذه المستخلصت النباتية ضد نوعين من الفطريات المسبة للأمراض النباتية الهلمة اقتصاييا وهما: - الفيوزاريوم أوكسوسبوريم ، والترناريا الترناتا.

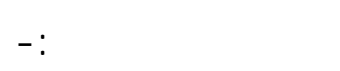
I - مظم الصفلت المدروسة (صفلت النمو الخضرية، وصفلت المحصول ومكوناته، وصفلت جودة رؤوس الثوم) تأثرت

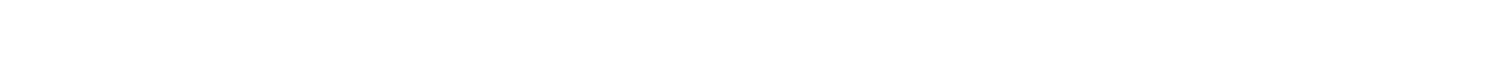

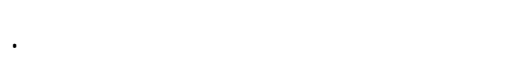

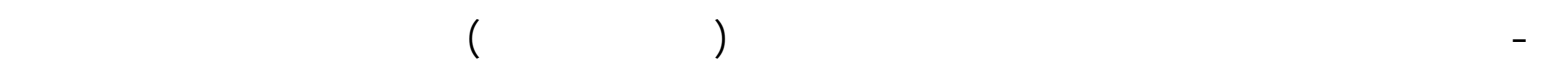
فضس إنتلجية الفدلن من محصول الثومن خلل إضلفة المحفزات الحيوية (هالك r + مستخلص الخميرة) للى نبلتات الثو النامية.

ب - إضفة المخفزات الحيوية (هالكس r، مستخلص الخميرة، هالكس r + مستخلص الخميرة) مع أى من المعاملات

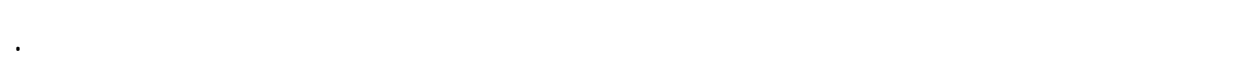

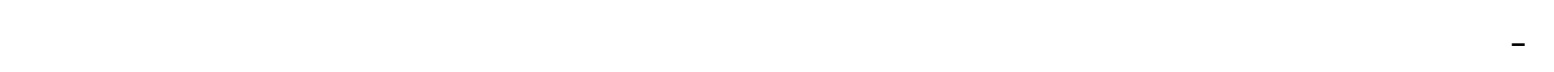

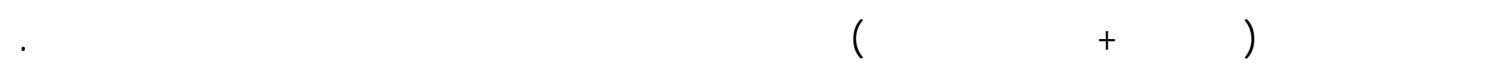

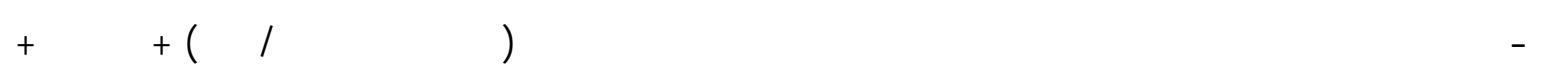

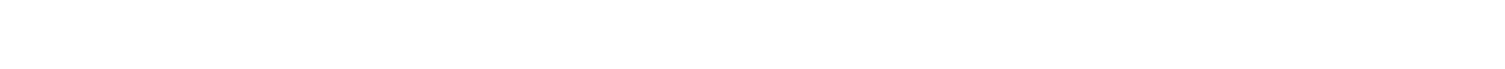
بكبريتا الأمونيوم ( r الكجم نيتروجين / فدلن) + هالكس + مستخلص الخميرة، كلنت مستخلصاتتها أعلى تشيطا

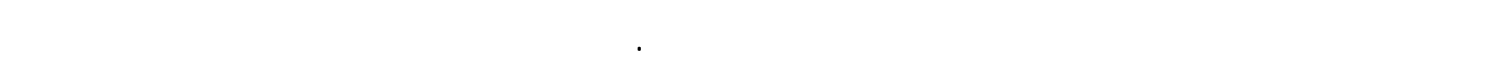

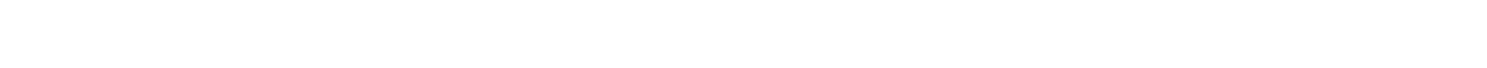

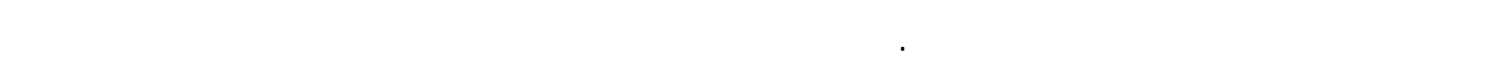
الفطريك المسبة للأمراض. أوصت نتائج الدرلسة ،وتحت ظورف هذه التجربة، بلمكانية إضلفة المحفزات الحيوية (هالكس + مستخلص

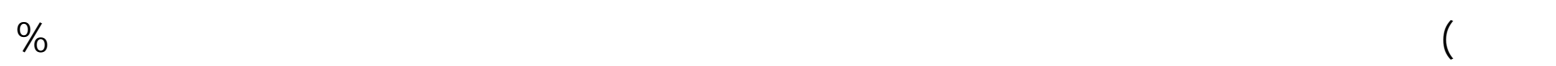
عن الكمية الموصى بها ( · r ا كجم نيتروجين الفدان). 